\title{
State of Art of Cancer Pharmacogenomics in Latin American Populations
}

Andrés López-Cortés ${ }^{1}$, Santiago Guerrero ${ }^{2}$, María Ana Redal ${ }^{3}$, Angel Tito Alvarado ${ }^{4}$ and Luis Abel Quiñones ${ }^{\text {,* }}$

1 Centro de Investigación Genética y Genómica, Facultad de Ciencias de la Salud Eugenio Espejo,

Universidad Tecnológica Equinoccial, Quito 170527, Ecuador; aalc84@gmail.com

2 Gene Regulation, Stem Cells and Cancer Programme, Centre for Genomic Regulation (CRG), The Barcelona Institute for Science and Technology, Universitat Pompeu Fabra (UPF), Barcelona 08003, Spain; santiago.guerrero@crg.eu

3 Instituto de Fisiopatología y Bioquímica Clínica, Facultad de Farmacia y Bioquímica, Universidad de Buenos Aires, Centro de Diagnóstico Molecular, MEDgenomica, Buenos Aires 1000-1499, Argentina; marianared@hotmail.com

4 Unidad de Bioequivalencia y Medicina Personalizada, Facultad de Medicina, Universidad de San Martín de Porres, Lima 12, Peru; eaa.alvarado@hotmail.com

5 Laboratory of Chemical Carcinogenesis and Pharmacogenetics, Department of Basic-Clinical Oncology, Faculty of Medicine, University of Chile, Santiago 70111, Chile

* Correspondence: lquinone@med.uchile.cl; Tel.: +56-2-681-7756; Fax: +56-2-682-2406

Academic Editors: Sabrina Angelini and Gloria Ravegnini

Received: 27 December 2016; Accepted: 10 March 2017; Published: 23 May 2017

\begin{abstract}
Over the past decades, several studies have shown that tumor-related somatic and germline alterations predicts tumor prognosis, drug response and toxicity. Latin American populations present a vast geno-phenotypic diversity due to the great interethnic and interracial mixing. This genetic flow leads to the appearance of complex characteristics that allow individuals to adapt to endemic environments, such as high altitude or extreme tropical weather. These genetic changes, most of them subtle and unexplored, could establish a mutational profile to develop new pharmacogenomic therapies specific for Latin American populations. In this review, we present the current status of research on somatic and germline alterations in Latin America compared to those found in Caucasian and Asian populations.
\end{abstract}

Keywords: cancer; single nucleotide polymorphism; precision medicine; Latin America; pharmacogenetics; pharmacogenomics

\section{Introduction}

The global increase in the cancer burden is raising an unprecedented awareness among governments of the need for action on cancer control. Countries in economic transition will experience marked increases in the number of cancer cases in the coming years as a result of rapid growth and ageing of their populations, coupled with increasing cancer rates as lifestyle and environments continue to evolve. Latin America is not an exception, with a suite of major social and demographic changes that underlie the predicted 1.7 million new cancer cases and one million cancer deaths in 2030, a $67 \%$ rise relative to 2012 estimates [1]. The incidence and mortality rates make cancer a public health problem; and strong economic investment has been made for the development of drugs sold at high prices. However, the progress on genome research in somatic and germline mutations is generating new pharmacogenomics treatments that can act in a personal or in a population manner, in accordance with the genomic profile of individuals, allowing governments and health entities to save economic resources. 
Somatic and germline mutations may have a great impact on disease prognosis and/or response to therapy. Somatic mutations appear after an oncogenic insult within the tumoral tissue while germline mutations are heritable alterations found within the individual. These mutations could be used as prognostic indicators of cancer outcome and/or predictive biomarkers to optimize therapy decisions among subpopulations of patients. Thus, genetic information can be used for both the selection of effective therapy and the avoidance of treatments with an unacceptable risk of adverse drug reactions [2]. In this review, we will present current status of research on somatic and germline alterations in Latin American compared with Caucasian and Asian populations, the burden of cancer and the imperative to perform comprehensive cancer pharmacogenomics studies, which may lead to the discovery of new clinical biomarkers, driver oncogenes and/or therapeutic targets.

\section{Somatic Genomics in Oncology}

A normal cell becomes cancerous by losing its ability to properly regulate key molecular processes involved in cellular replication. This initial genetic alteration can be a simple mutation in the DNA or a deep genetic deletion or amplification. This malignant cell, which carries the founder somatic genome, proliferates and additional genetic and/or epigenetic alterations (e.g., DNA methylation) can be acquired [3]. These genomic aberrations can further provide cellular advantages for angiogenesis and metastasis progression [4]. The initial and acquired alterations determine the aggressiveness of the tumor and the sensitivity or resistance to therapy. Thus, identifying driver somatic alterations is essential to predict tumor prognosis and response to treatment [5].

Cancer research has evolved in parallel with high-throughput omics technologies, leading to the development of a personalized genomic-based therapy. This tailored treatment not only takes into account the clinical aspects of each patient, but also, and most importantly, the molecular characteristics of their tumors. Thus, to offer a precise anticancer therapy, personalized oncology identifies druggable cancer driver proteins based on their genomic alterations (somatic mutations, copy number alterations and mRNA expression) and differences between human populations [6,7].

Nowadays, for instance, anti-cancer therapy in non-small-cell lung cancer (NSCLC) is tailored according to the patient genomic signature. In NSCLC, two major driver oncogenes are found: epidermal growth factor receptor (EGFR) and anaplastic lymphoma kinase (ALK) [8]. Since EGFR and $A L K$ mutations are mutually exclusive, EGFR-mutated patients are treated with EGFR tyrosine kinase inhibitors (TKIs), such as gefitinib or erlotinib, while ALK-altered patients are treated with specific ALK inhibitors, such as crizotinib or ceritinib. Concerning human populations, about $15 \%$ of Caucasian and $40-50 \%$ of Asian patients with lung adenocarcinoma present alterations in the EGFR gene. On the contrary, KRAS (Kirsten rat sarcoma viral oncogene homolog) mutations are observed in $\sim 15 \%$ of NSCLC Asians patients and $\sim 30 \%$ of NSCLC Caucasians patients. However, these alterations are found in parallel with many others and therefore KRAS is not considered as a driver oncogene. Other mutations have also been reported in ROS1, BRAF, MET, RET, and Her2 genes with an incidence rate of $1-3 \%$. Regarding $A L K$ genomic subtype, $3-7 \%$ of NSCLC patients present an activated form of $A L K$, formed by a gene fusion event between $A L K$ and the echinoderm microtubule-associated protein-like 4 (EML4). This abnormal protein is involved in cell proliferation as well as apoptosis inhibition [8].

In Chinese, Korean, and Japanese female non-smokers with lung adenocarcinoma (AD), there is a high prevalence of EGFR mutations clustered between exons 18 and 21. These mutations are useful biomarkers of EGFR TKIs response and can predict a better clinical outcome after gefitinib treatment. Thus, clinical decisions can be taken not only based on the genomic subtype but also on ethnicity $[6,9]$.

Recently, Chen et al. (2016) analyzed The Cancer Genome Atlas Network (TCGA) NSCLC genomic database $(n=1023)$ to classify NSCLC into nine subtypes: three within squamous cell carcinoma (SQCC) and six within AD [10]. SQCC subtypes were related with transcriptional targets of SOX2 or $p 63$. Regarding the six AD subtypes, one shared molecular characteristics with neuroendocrine tumors, two showed a CPG island methylator phenotype, and three manifested high $p 38$ and mTOR pathway 
activation. Although detection of $A L K$ and EGFR mutations is widely accepted as a standard procedure for NSCLC personalized therapy, this molecular classification could provide new information to detect clinical biomarkers or therapeutic targets [10].

In colorectal cancer (CRC), 5-fluorouracil (5-FU) based chemotherapy has been accepted as the first line therapy and is applied for neoadjuvant and adjuvant treatment of CRC patients. Recently, the incorporation of anti-EGFR monoclonal antibodies into the traditional chemotherapy has greatly improved the efficacy and is now also used to treat metastatic colorectal cancer (mCRC) [11,12]. However, EGFR-based therapies are only efficient in a subgroup of patients. This efficacy has been related to the mutational profile of the KRAS gene [13]. Several studies have clearly demonstrated that only mCRC patients with wild type (WT) KRAS respond to anti-EGFR treatment. KRAS is a member of the RAS gene family (HRAS, KRAS, and NRAS), which encodes highly similar membrane-localized $\mathrm{G}$ proteins [14]. Members of this family have been associated with tumorigenesis due to their implication in key cellular processes, such as cell growth and apoptosis $[15,16]$. In particular, KRAS has been implicated in several types of malignant tumors, including colon, lung and pancreatic cancer $[17,18]$. Several activating mutations in the KRAS gene, resulting in EGFR-independent activation of the mitogen-activated protein kinase pathway $(M A P K)$, have been reported. The most frequent alterations are found in codon $12(\sim 77 \%$ of all reported KRAS mutations) and codon $13(\sim 23 \%)$ [19]. Although alterations in other positions, such as codon 61 , have also been reported, they only account for $1-4 \%$ of KRAS reported variants. The clinical relevance of those variants in CRC and mCRC treatment is still unknown. The prevalence of KRAS mutations differs amongst human tumors. Previous studies have shown that the frequency of mutation is around $30-40 \%$ in CRC and we reported $32 \%$ of mutations [20]. These observations are similar when comparing different ethnic groups [18,21,22]. For instance, the mutation frequency of KRAS G35A (codon 12) was 0.71 and of KRAS G38A (codon 13) was 0.29 in the Mexican population [18]. Identifying the mutational profile of $K R A S$ in each patient is required to apply the best possible treatment: patients with the wild type KRAS could receive monoclonal antibodies against $E G F R$, while KRAS mutated patients have been related with poor prognosis and no-response to anti-EGFR therapies [23-25].

In cutaneous melanoma, Akbani et al. (2015), proposed a classification into four subtypes based on the most significantly mutated genes: BRAF (47\%), RAS (29\%), NF1 (9\%), and Triple-WT (15\%). These proteins are involved in the mitogen-activated protein (MAP) kinase pathway. In this process, activated RAS proteins stimulate the RAF kinases ARAF, BRAF and RAF1, which, in turn, phosphorylate MEK kinases. Activated MEK kinases phosphorylate ERK kinases that subsequently regulate multiple cellular processes involved in oncogenesis. In contrast, NF1 protein acts as a negative regulator of RAS signaling. These genomic signatures allow clinicians to administrate an accurate treatment for each patient. For instance, $B R A F$-mutated patients receive BRAF inhibitors, such as vemurafenib or dabrafenib; while RAS patients are likely to respond to MEK inhibitors [26].

Despite the effort in understanding the above TCGA genomic classifications, these studies have been performed using tumor samples predominantly from Caucasians. Regarding the TCGA melanoma classification, $96 \%$ of samples were obtained from White populations, leaving other populations highly under-represented: 1.4\% Hispanic/Latino, 0.3\% Black/African American and 2\% Asian [26]. Concerning the TCGA NSCLC genomic classification, $69 \%$ of samples came from White populations, $1 \%$ from Hispanic/Latino and 30\% unknown [10]. On the other hand, the PanCancer Analysis of Whole Genomes (PCAWG) Project is coordinated by the TCGA and the International Cancer Genome Consortium (ICGC), and has so far carried out 74 projects about all types of cancer in more than 25,000 genomes that mainly belong to Caucasian and Asian populations [27,28]. Nevertheless, Latin America populations have different geno-phenotypic characteristics due to the great inter-ethnic mixing and environmental aspects. For instance, Latin America populations are highly exposed to ultraviolet (UV) radiation due to high altitude cities (i.e., Quito or La Paz), tropical weather and ozone depletion in some regions (South America). In melanoma, this could greatly increase UV-based mutations and completely change the mutational landscape defined Akbani et al. (2015) [26]. 


\section{Germline Pharmacogenomics in Oncology}

For more than 50 years, it has been proven that the genetic differences among people contribute to interindividual responses to drugs commonly used in cancer treatments. Pharmacogenetics and pharmacogenomics determine these genetic differences to predict drug safety, toxicity and efficiency among individuals and populations. Pharmacogenetics studies the variability in drug response due to heredity focusing on genes implicated in drug metabolism, while pharmacogenomics enlarges the understanding of drug response by studying all genes in the genome. The term pharmacogenomics was associated with the Human Genome Project (HGP). According to the HGP, 99.9 percent of the information found in around 23,000 human genes is identical among individuals, whereas the remaining 0.1 percent of genes is specific to each individual. This difference may be influential in the susceptibility to develop any type of cancer or to determine how an individual reacts to different treatments and how drugs are metabolized $[29,30]$.

The term pharmacogenetics encompasses two disciplines: pharmacology and genetics. Pharmacology aims to understand how drugs act on the body and genetics is the study of genes and their variation and heredity among individuals. Thus, pharmacogenetics tries to determine the genetic cause of unexpected drug responses [31]. It focuses on the role played by the genetic variation in pharmacokinetics, such as drug absorption, distribution, metabolism, and excretion; as well as in pharmacodynamics, such as drug-response proteins, receptors, channels, and transporters [29,30,32]. On the other hand, pharmacogenomics determine genetic differences in a population-based manner that may explain drug response and toxicity. The human genome is composed of 3.1 billion nucleotide bases and genetic variations can be found among human populations. These variations can be classified in single nucleotide polymorphisms (SNPs), deletions, amplifications, insertions or tandem repeats [33]. These variants, which are overall considered as the germline genome, can be present in genes that codify for proteins implicated in key molecular processes that affect drug response [5]. In this section, we describe polymorphisms in drug transporters, drug targets, and drug-metabolizing enzymes.

\subsection{Single Nucleotide Polymorphisms}

During the 1990s, after digesting DNA sequences, the existence of variations in the cutting sites that exactly belonged to a single nucleotide was found. Today, the 1000 Genomes Project Consortium (phase 3) identified about 84.7 million SNPs in 26 human populations, along with 3.6 million short insertions/deletions (indels) and 60,000 structural variants [34]. Likewise, the variants can be found both in coding sequences called exons and non-coding sequences called introns, and can be responsible for a higher or lower tendency to develop illnesses. The SNPs may or may not cause changes in the essential information of nucleotides, and, therefore, the gene, but regardless of the case, their relation to pathologies, such as different types of cancer, is becoming clearer [35].

The SNPs in drug-metabolizing enzymes, transporters, and receptors have relevant effects in the efficiency and toxicity of some drugs [36,37]. Consequently, science and technology make progress everyday in order to create drugs that can be used in personalized treatments for patients suffering from different types of cancer. Despite the fact that environmental factors, age, type of nutrition, and health condition may be influential in the response to the pharmacological treatment, the genomic information is the key to creating personalized drugs with greater efficacy and safety. The SNPs are the most common variation in the DNA sequence, whereas mutations are uncommon variations, but the main cause of genetic disorders [38]. From the point of view of evolution, SNPs are interesting to analyze. First, the frequency of SNPs in exons and introns is very similar: $1 / 346$ base pairs (bp) and $1 / 354 \mathrm{bp}$, respectively. The SNPs of exons could be related to illnesses, whereas the SNPs of introns, especially all the perigenetics, are related to variations in the alternative splicing and non-expression sites for miRNAs. When comparing SNPs between chimpanzees and humans, little variations in number $(0.6 \%)$ have been found. After analyzing their distribution in the genome, the difference is of some $32 \%$. Additionally, it has been discovered that the SNPs vary among populations. For instance, African American people and African people have more SNPs than Europeans and Asians (93:17) [34]. 


\subsection{Drug Transporters}

Pharmacogenomics identifies the inherited genetic variations that may predict patients' response to different types of chemotherapy more efficiently. The genetic variations significantly change among ethnic groups, and the assessment of the haplotypes may generate results that are highly correlated to the phenotype [39].

Considering the polymorphisms in drug transporters, the SLCO1B1 gene presents the SNP SNP rs4149056, also known as T37041C, in the exon 5, chromosome 12. This gene encodes the organic anion-transporting polypeptide 1B1 (OATP1B1) protein, which is a membrane transport protein located mainly in the liver and regulates the circulation of organic anions [40,41]. Several SNPs (i.e., T37041C) that are involved in the folate pathway have been implicated in the pharmanokinetics and effects of methotrexate [42]. In addition, this polymorphism increases systemic exposure to simvastatin and the risk of muscular toxicity [43-45]. According to the 1000 Genomes Project (phase 3), the allele frequency of T37041C is $0.82(\mathrm{~T})$ and $0.18(\mathrm{C})$ in Colombia, $0.92(\mathrm{~T})$ and $0.08(\mathrm{C})$ in Mexico, $0.86(\mathrm{~T})$ and 0.14 (C) in Peru, and 0.88 (T) and 0.12 (C) in Puerto Rico, in contrast with 0.86 (T) and 0.14 (C) in Han Chinese population, $0.86(\mathrm{~T})$ and $0.14(\mathrm{C})$ in British population, and $0.88(\mathrm{~T})$ and $0.12(\mathrm{C})$ in Iberian population [34] (Table 1).

Table 1. Allele frequencies for clinically relevant germline polymorphisms in populations worldwide according to the 1000 Genomes Project (Phase 3) and HapMap Project.

\begin{tabular}{|c|c|c|c|c|}
\hline \multirow{2}{*}{ Gene } & \multirow{2}{*}{ Polymorphism } & \multicolumn{3}{|c|}{ Human Populations } \\
\hline & & Latin America & Caucasian & Asian \\
\hline SLCO1B1 & $\begin{array}{l}\mathrm{T} 37041 \mathrm{C} \\
(\mathrm{rs} 4149056)\end{array}$ & $\begin{array}{c}\text { Colombia: } 0.08(\mathrm{C})^{* *} ; \\
\text { Mexico: } 0.08(\mathrm{C}) ; \\
\text { Peru: } 0.14(\mathrm{C}) \\
\text { Puerto Rico: } 0.12(\mathrm{C})\end{array}$ & $\begin{array}{l}\text { Spain: } 0.12(\mathrm{C}) \\
\text { British: } 0.14(\mathrm{C}) \\
\text { Finland: } 0.18(\mathrm{C}) \\
\text { Italy: } 0.21(\mathrm{C})\end{array}$ & $\begin{array}{c}\text { Han Chinese: } 0.14(\mathrm{C}) \text {; } \\
\text { Bangladesh: } 0.05(\mathrm{C}) \text {; } \\
\text { Japan: } 0.12(\mathrm{C}) ; \\
\text { Vietnam: } 0.10(\mathrm{C})\end{array}$ \\
\hline TYMS & $\begin{array}{c}\operatorname{TSER}^{*} 2 / * 3 / * 4 \\
(\mathrm{rs} 34743033)\end{array}$ & $\begin{array}{c}\text { Self-described } \\
\text { Hispanic: } 0.41\left({ }^{*} 2\right){ }^{* * *} \text {; } \\
\text { Self-described } \\
\text { Hispanic: } 0.59\left({ }^{*} 3\right) \text {; } \\
\text { Peru: } 0.66\left({ }^{*} 4\right) ; \\
\text { Mexico: } 0.65\left({ }^{*} 4\right)\end{array}$ & $\begin{array}{c}\text { Self-described } \\
\text { Caucasian: } 0.45\left({ }^{*} 2\right) \text {; } \\
\text { Self-described } \\
\text { Caucasian: } 0.55\left({ }^{*}\right)\end{array}$ & $\begin{array}{c}\text { Pacific Rim: } 0.11(* 2) \text {; } \\
0.89(* 3)\end{array}$ \\
\hline \multirow{4}{*}{ TPMT } & $\begin{array}{c}\mathrm{TPMT}^{* 2} \\
\text { (rs1800462) }\end{array}$ & $\begin{array}{l}\text { Colombia: } 0.01(\mathrm{G}) ; \\
\text { Mexico: } 0.00(\mathrm{G}) ; \\
\text { Peru: } 0.01(\mathrm{G}) ; \\
\text { Puerto Rico: } 0.01(\mathrm{G})\end{array}$ & $\begin{array}{l}\text { Spain: } 0.01(\mathrm{G}) ; \\
\text { British: } 0.01(\mathrm{G}) ; \\
\text { Finland: } 0.00(\mathrm{G}) ; \\
\text { Italy: } 0.99(\mathrm{C}), 0.01(\mathrm{G})\end{array}$ & $\begin{array}{c}\text { Han Chinese: } 0.00(\mathrm{G}) \text {; } \\
\text { Bangladesh: } 0.00(\mathrm{G}) ; \\
\text { Japan: } 0.00(\mathrm{G}) ; \\
\text { Vietnam: } 0.00(\mathrm{G})\end{array}$ \\
\hline & $\begin{array}{l}\mathrm{TMPT}^{* 3 \mathrm{~A}} \\
(\mathrm{rs} 1800460)\end{array}$ & $\begin{array}{l}\text { Colombia: } 0.01(\mathrm{~T}) ; \\
\text { Mexico: } 0.04(\mathrm{~T}) ; \\
\text { Peru: } 0.06(\mathrm{~T}) ; \\
\text { Puerto Rico: } 0.05(\mathrm{~T})\end{array}$ & $\begin{array}{c}\text { Spain: } 0.04(\mathrm{~T}) ; \\
\text { British: } 0.03(\mathrm{~T}) ; \\
\text { Finland: } 0.03(\mathrm{~T}) ; \\
\text { Italy: } 0.01(\mathrm{~T})\end{array}$ & $\begin{array}{c}\text { Han Chinese: } 0.00(\mathrm{~T}) \text {; } \\
\text { Bangladesh: } 0.02(\mathrm{~T}) \text {; } \\
\text { Japan: } 0.00(\mathrm{~T}) ; \\
\text { Vietnam: } 0.00(\mathrm{~T})\end{array}$ \\
\hline & $\begin{array}{l}\mathrm{TPMT}^{* 3 C} \\
(\mathrm{rs} 1142345)\end{array}$ & $\begin{array}{l}\text { Colombia: } 0.02(\mathrm{C}) ; \\
\text { Mexico: } 0.05(\mathrm{C}) ; \\
\text { Peru: } 0.06(\mathrm{C}) ; \\
\text { Puerto Rico: } 0.10(\mathrm{C})\end{array}$ & $\begin{array}{l}\text { Spain: } 0.04(\mathrm{C}) \text {; } \\
\text { British: } 0.03(\mathrm{C}) \text {; } \\
\text { Finland: } 0.03(\mathrm{C}) \text {; } \\
\text { Italy: } 0.01(\mathrm{C})\end{array}$ & $\begin{array}{c}\text { Han Chinese: } 0.01(\mathrm{C}) \text {; } \\
\text { Bangladesh: } 0.03(\mathrm{C}) \text {; } \\
\text { Japan: } 0.02(\mathrm{C}) ; \\
\text { Vietnam: } 0.03(\mathrm{C})\end{array}$ \\
\hline & $\begin{array}{l}\mathrm{TPMT}^{*} 4 \mathrm{~A} \\
\text { (rs1800584) }\end{array}$ & $\begin{array}{l}\text { Argentina: } 0.03(\mathrm{~A}) \\
\text { Mexico: } 0.04(\mathrm{~A})\end{array}$ & $\begin{array}{l}\text { Utah residents with } \\
\text { Northern and Western } \\
\text { European ancestry: } \\
0.01 \text { (A); Italy: } 0.01 \text { (A) }\end{array}$ & - \\
\hline UGT1A1 & $\begin{array}{l}\text { UGT1A1*6 }^{*} \\
\text { (rs4148323) }\end{array}$ & $\begin{array}{c}\text { Colombia: } 0.03(\mathrm{~A}) ; \\
\text { Mexico: } 0.02(\mathrm{~A}) ; \\
\text { Peru: } 0.00(\mathrm{~A}) ; \\
\text { Puerto Rico: } 0.00(\mathrm{~A})\end{array}$ & $\begin{array}{l}\text { Spain: } 0.00(\mathrm{~A}) \text {; } \\
\text { British: } 0.00(\mathrm{~A}) \text {; } \\
\text { Finland: } 0.04(\mathrm{~A}) \text {; } \\
\text { Italy: } 0.00(\mathrm{~A})\end{array}$ & $\begin{array}{c}\text { Han Chinese: } 0.23(\mathrm{~A}) \text {; } \\
\text { Bangladesh: } 0.03(\mathrm{~A}) ; \\
\text { Japan: } 0.13(\mathrm{~A}) ; \\
\text { Vietnam: } 0.07(\mathrm{~A})\end{array}$ \\
\hline
\end{tabular}

${ }^{* *}$ Frequency of minor allele, ${ }^{* * *}$ Number of repeats per mutation. 


\subsection{Drug Targets}

As for the polymorphisms in drug targets, 5-fluorouracil (5-FU) inhibits the thymidylate synthase (TYMS) enzyme through dUMP. The thymidine triphosphate is essential to repair and synthesize the DNA. It is generated from the TYMS [46]. The TYMS inhibition is a well-known target for 5-FU. However, there is evidence regarding the overexpression of TYMS in tumors and the resistance to the TYMS-targeted agents [47]. The TYMS expression levels are regulated by polymorphic tandem repeats in the TYMS enhancer region (TSER) (rs34743033); the more repeats, the more enzyme activity. Therefore, three tandem repeats (TSER $* 3$ ) have higher mRNA expression levels in the tumor tissue unlike TSER ${ }^{2}$ and that is correlated to a lower response reported to 5-FU [48]. These results suggest that the TSER genotyping is essential to select patients capable of responding to a treatment with 5-FU. On the other hand, a large prospective analysis of Niedzwiecki et al. (2016) found that it is useless to assign a specific adjuvant therapy to treat colorectal cancer by measuring the TYMS levels in tumors [49]. According to Marsh et al. (2015), the TSER polymorphism had a variant allele frequency of 0.66 in Peruvian population and 0.65 in Mexican population [50].

\subsection{Drug-Metabolizing Enzymes}

There are more than 30 families of drug-metabolizing enzymes; the genes that encode these proteins are capable of accumulating genetic variants that cause functional changes; therefore, drug metabolism is affected [51]. The antitumor action of the 6-mercaptopurine (6-MP), mainly used to treat leukemia, lies in inhibiting the generation of nucleotides, which are essential for RNA and DNA synthesis. The $S$-methylation of 6-MP, important in the development of inactive metabolites, is catalyzed by thiopurine methyltransferase (TPMT) [52,53]. According to Evans et al. (1991), there are patients that have presented hematologic toxicity when treated with 6-MP under the presence of the TPMT 2 , $\mathrm{TMPT}^{*} 3 \mathrm{~A}$, and TPMT $3 \mathrm{C}$ polymorphisms [53]. Each one of these mutant alleles encodes TPMT proteins that are rapidly degradated, generating enzyme deficiency. The frequencies of the TPMT alleles differ among ethnic groups [54,55]. For instance, the frequency of TPMT mutations was 0.31 (TPMT*3A), 0.07 (TPMT ${ }^{*}$ ), and 0.03 (TPMT*4) in Argentina; 0.00 (TPMT*2), 0.09 (TPMT*3B), and 0.08 (TPMT*3C) in Peru; and 0.00 (TPMT*2), 0.04 (TPMT*3B), and 0.04 (TPMT*3C) in Mexico [50] (Table 1). Consequently, a profile analysis of the TPMT deficiency is recommendable to determine a right dose and to avoid toxicity in a treatment with 6-MP on patients with acute lymphatic leukemia [56].

Irinotecan is an antineoplasic drug whose active metabolite is the 7-ethyl-10-hydroxycamptothecin (SN-38), which is capable of inhibiting the topoisomerase-I [57]. Irinotecan is a popular chemotherapy agent since its antitumoral activity is strong. The clinical pharmacogenetics of irinotecan is associated with the presence of SNPs in the UDP-glucuronosyltransferase 1A1 (UGT1A1) enzyme, which is in charge of the glucuronidation of SN-38 to generate the inactive metabolite SN38G [58]. The presence of several repeats TA in the UGT1A1 gene promoter generates reduced enzyme expression and activity $[59,60]$. The allele frequencies of UGT1A $1^{*} 6$ reach up to $3.5 \%$ in a Caucasian population (Finland), whereas the frequency in Asian populations is higher. In Latin American population, the allele frequencies of UGT1A1*6 was 0.00 in Peru, and 0.13 in Mexico [50] (Table 1).

The cytochrome P450 enzymes are an important family of drug metabolizing enzymes since they catalyze metabolism of more medications than other enzyme families. Debrisoquine hydroxylase (CYP2D6) is the most typical polymorphism of the P450 enzymes worldwide. Subsequently, $>30$ drugs were found to be substrates for CYP2D6. Polymorphisms of the CYP1A1 gene are considered as possible breast cancer risk factors since they act as mediators in the tumorigenesis caused by the metabolism of estrogens, metabolic pathway where the enzyme encoded by this gene is involved because it catalyzes several steps in the biosynthesis of steroid hormones, such as estrogen. Its derivative metabolites have an important anti-proliferative and anti-angiogenic activity, whereas other products of the metabolism of estrogen may join the DNA and damage it, suggesting that estrogen and the intermediary products of its metabolism may turn into potential carcinogens [61]. 


\subsection{Pharmacogenomics in Clinical Practice}

The Canadian Pharmacogenomics Network for Drug Safety (CPNDS), the Royal Dutch Association for the Advancement of Pharmacy (DPWG), and the Clinical Pharmacogenetics Implementation Consortium (CPIC) have created and published precise guidelines for the application of pharmacogenomics in clinical practice [62-64]. However, according to a research conducted by Quiñones et al. (2014), there are important barriers to implement the use of pharmacogenomics testing in clinical practice. Some of the barriers that can be found in Latin America are the following: Need for a regional clear guidelines for the use of pharmacogenomics, fragmentation of healthcare systems, insufficient use of electronic records information of patients, lack of knowledge in pharmacogenomics on the part of clinicians, insufficient pharmacogenomic characterization of the target population, insufficient characterization of pharmacogenetic variability in Latin America, lack of health institutions that focus on the development of pharmacogenetic tests, healthcare system do not promote pharmacogenomics use, concerns about test costs, need for implementation of gene/drug pairs, lack of clear information about mutations actually has functional relevance, need for demonstration of clinical validity and utility of pharmacogenomics test, reluctance of clinicians to use genetic biomarkers as markers of clinical response, insufficient definition of the clinical impact of SNPs on specific drugs, and ethical, legal, and social implications [65].

However, overcoming the obstacles previously mentioned with planning will make it possible to get several benefits. Pharmacogenomic tests are capable of improving patient safety; in other words, individuals who are likely to experience dangerous reactions to drugs could be identified, leading to the adjustment of drug doses in a personalized manner. Pharmacogenomics allows for improving the investment in public and private health in the Latin American countries, saving time and resources that doctors and patients need, finding adequate treatments based on "trial and error". An additional benefit has to do with the improvement of drug dosage used in the different treatment plans against cancer, starting from the genetic chart of each patient rather than their age and weight [31].

Pharmacology of the future intends to conduct individualized pharmacotherapeutic treatment for the manifestation of a disease and the appropriate dose for the therapeutic effect in a given patient, minimizing the risk of adverse reactions. In order to implement successful pharmacogenomics tests in clinical practice at the hospitals in Latin America, it is important to understand the interethnic and intraethnic genetic variability of its populations $[60,65]$.

\section{Germline Cancer Predisposition in Latin America}

Countries in Latin America have undergone significant economic and social changes during the last few decades [66,67]. Declines in reproductive patterns, urbanization and increases in life expectancy are leading to major changes in the population structure and associated increases in the burden of non-communicable diseases, including cancer $[66,68]$.

The GLOBOCAN project has estimated that approximately 14 million cancer cases and 8.2 million cancer deaths were estimated to have occurred worldwide in 2012, with one million cancer cases and more than half a million cancer deaths occurring in Latin America [69]. Projections indicate that by the year 2030, 1.7 million new cases and one million cancer deaths are expected to occur in the region because of ageing and population growth [1,70]. In 2012, GLOBOCAN indicates that the most common cancer diagnoses and causes of cancer-related death in Latin America region were prostate, lung, colorectum, and stomach cancers for males and breast, cervix, colorectum and lung for females [1]. Although cancer incidence in Latin America is, in general, lower than the cancer incidence in more developed regions of the world, mortality is remarkably higher. This may be explained in part by more advanced stages at diagnosis and by poorer access to cancer diagnostic, screening and treatment services [71]. 


\subsection{Cancer Incidence and Mortality in Latin America}

The incidence rate has increased over the years and the high mortality rate in Latin American populations in contrast with other populations worldwide are warning signs for governments and public and private health institutions to invest in pharmacogenomics research and in the development of effective therapeutic bulls eye to guide medicinal accuracy. The incidence and mortality rates of the most prevalent types of cancer in Latin American populations are detailed below.

Breast cancer was the most frequent cancer diagnosis among females in Latin America, except in Bolivia and El Salvador. The highest age-standardized incidence rates were in Argentina, Brazil, and Uruguay (between 67.7 and 71.9 per 100,000 inhabitants) and the lowest in Bolivia (12.7) and El Salvador (7.9) (Figure 1a). BC was one of the two leading causes of cancer death among females, with the exceptions of Ecuador, Peru, Nicaragua, and Guatemala [72] (Figure 1b). Prostate cancer was the most common malignancy diagnosed among males in Latin America, except in El Salvador and Cuba where it ranked second (after stomach and lung, respectively). During the most recent five-year period (2003-2007), the incidence of prostate cancer varied by six-fold across this region. The highest age-standardized rates were observed in French Guyana (147.1) and Brazil (91.4) and the lowest were in Mexico (28.9) and Cuba (24.3). Prostate cancer was one of the two leading causes of cancer deaths in males in Latin America, except in Chile, Argentina, Colombia and El Salvador where it ranked third. Mortality rates varied by four-fold, with the highest rates seen in Belize (28.9), Uruguay (21.8), and Cuba (24.1) and the lowest in Peru, Nicaragua, and El Salvador (rates between 6.8 and 9.7) [73]. Lung cancer incidence rates ranged from as high as 50.1 among males in Uruguay, to as low as 1.1 among females in El Salvador. In Central America, Cuba had by far the highest incidence of lung cancer for both males and females (39.2 and 18.9, respectively), with lung cancer also ranking in the first place for cancer incidence among males. The South American countries where the highest male incidence rates were observed were Uruguay (50.1), Chile (33.8) and Argentina (30.5). Among females, the pattern was slightly different with the highest incidence rates found in Chile (12.1) and Brazil (11.5). The highest male-to-female incidence ratio was found in Uruguay (5.5) and the lowest in Bolivia (0.6). For mortality, the countries with the highest rates among both males and females in Central America were Cuba (39.0 and 18.1), Belize (15.9 and 6.5) and Mexico (13.2 and 5.4). Among males, lung cancer mortality patterns with the highest rates were Uruguay (44.5), Argentina (30.8) and Chile [39]. In females, countries with the highest lung cancer mortality rates were Venezuela (9.3), Argentina (7.8), Colombia (7.7) and Brazil (7.6) [74]. During the last five years, stomach cancer was one of the five most frequently diagnosed cancers in Argentina, Brazil, Bolivia, Chile, Colombia, Costa Rica, Ecuador, El Salvador, French Guyana and Peru, and one of the five leading causes of cancer death in most Latin American countries (except for females in Argentina, Cuba, and Suriname). In males, the highest incidence rates of stomach cancer were observed in Chile (29.1) followed by Costa Rica, Colombia, Ecuador and Brazil, and Peru (19.2 to 26.5) while the lowest rates were observed in Mexico, Bolivia and El Salvador (3.3 to 4.6). In females, the highest rates were seen in Peru, Costa Rica, Ecuador, Colombia, Chile and Brazil (9.7-15.1) and the lowest rates were in Mexico, Bolivia and El Salvador (3.0). Mortality rates of stomach cancer varied by 5-6-fold. In males, the highest mortality rates were observed in Chile and Costa Rica (20.1-24.6) and the lowest rates were in Suriname, Cuba and Paraguay (5.0-7.1). In females, the highest rates were seen in Guatemala (17.1) followed by Ecuador and Peru (10.5-11.2) and the lowest rates were in Paraguay, Argentina, Cuba and Suriname (2.9-3.9) [75]. Colorectal cancer was among the five most common cancers diagnosed in males and females (except in El Salvador, where it ranked seventh and ninth, respectively) and one of the eight most frequent causes of cancer deaths in Latin America. The highest incidence rates for males and females were observed in Uruguay (34.2 and 24.7, respectively), Brazil (27.7 and 21.5) and in males in Argentina (25.2), whereas the lowest rates were in El Salvador (1.5 and 1.3). Overall, mortality rates were below 10 for both males and females, except in Uruguay (17.7 for males and 12.0 for females), Cuba (10.0 for males and 11.3 for females) and males in Argentina (14.6) [76]. Additionally, cervical cancer was the leading female cancer diagnosis in El Salvador and Bolivia and the second leading female cancer in Mexico, Argentina, 
Colombia, Ecuador, French Guyana, and Peru. The highest incidence was observed in French Guyana and El Salvador (29.7 and 28.9), while Costa Rica, Chile, Mexico and Cuba showed rates under 15. The highest mortality rates were observed in Belize and Paraguay (17.4 and 15.3, respectively), and in descending order: El Salvador, Nicaragua, Venezuela, Suriname, and Ecuador, with rates between 10 and 15. The lowest mortality was observed in Chile, Uruguay, Brazil and Costa Rica (rates ranging from 6.0 to 7.3$)$ [77].

(a) Incidence per 100,000 inhabitants

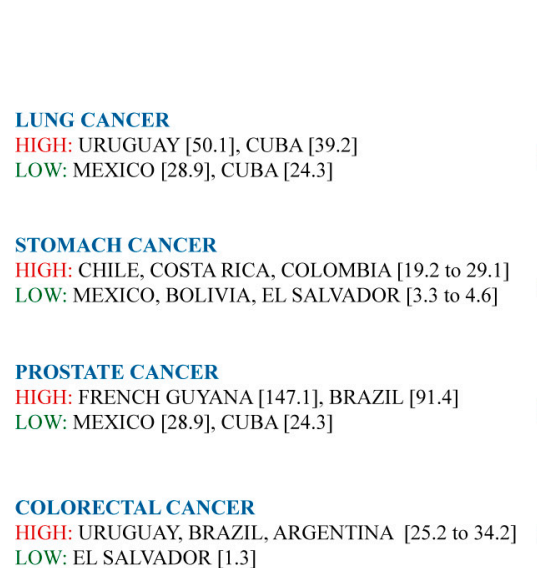

HIGH: URUGUAY, BRAZIL, ARGENTINA [25.2 to 34.2]
LOW: EL SALVADOR [1.3] (b) Mortality per 100,000 inhabitants

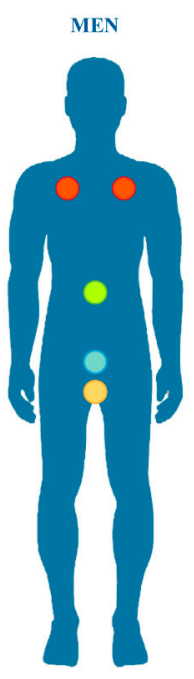

LUNG CANCER

HIGH: URUGUAY [44.5], ARGENTINA [30.8]

LOW: EL SALVADOR [4.9], NICARAGUA [5.2]

STOMACH CANCER

HIGH: CHILE, COSTA RICA [20.1 to 24.6]

LOW: SURINAME, CUBA, PARAGUAY [5.0 to 7.1]

PROSTATE CANCER

HIGH: BELIZE [147.1], URUGUAY [21.8]

LOW: PERU, NICARAGUA, EL SALVADOR [6.8 to 9.7]

COLORECTAL CANCER

HIGH: URUGUAY [17.7], ARGENTINA [14.6]

LOW: EL SALVADOR [2.2]
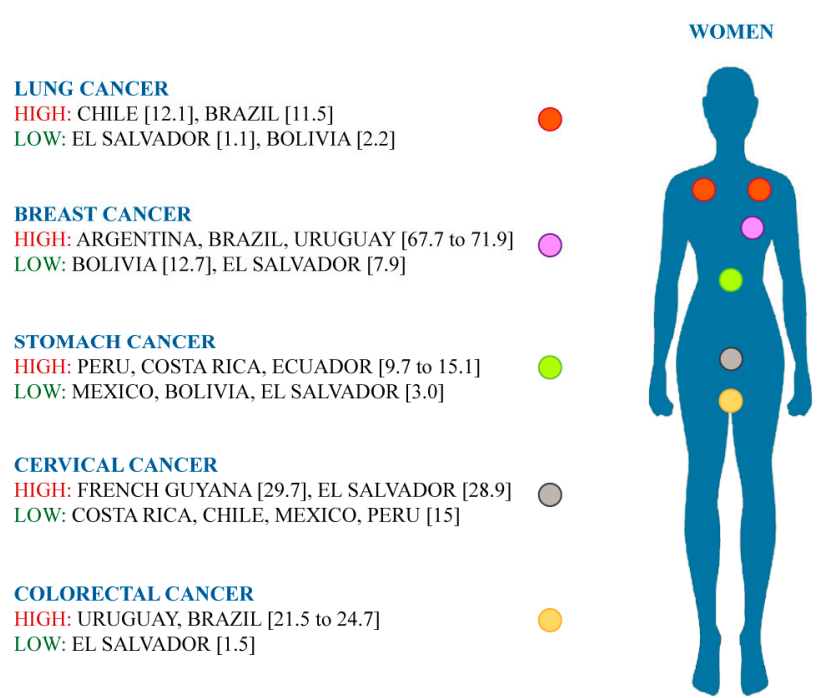

LUNG CANCER

HIGH: VENEZUELA [9.3], ARGENTINA [7.8] LOW: PARAGUAY [3.2], NICARAGUA [3.2]

BREAST CANCER

HIGH: URUGUAY [20.5], ARGENTINA [19.4] LOW: GUATEMALA [3.9], EL SALVADOR [4.1]

STOMACH CANCER

HIGH: GUATEMALA [17.1], PERU [11.2]

LOW: PARAGUAY, CUBA, SURINAME [2.9 to 3.9]

CERVICAL CANCER

HIGH: BELIZE [17.4], PARAGUAY [15.3]

LOW: EL SALVADOR, NICARAGUA [10 to 15]

COLORECTAL CANCER

HIGH: URUGUAY [12.0], ARGENTINA [18.9]

LOW: EL SALVADOR [2.4]

Figure 1. Cancer incidence and mortality in Latin America. (a) Cancer incidence per 100,000 inhabitants in men and women; (b) Cancer mortality per 100,000 inhabitants in men and women.

\subsection{Genotyping the Latin American Populations with Cancer}

It is known that some genetic markers (characteristics of proteins, enzymes, chromosomes, and immunology) are related to different types of cancer. This means that a person with a specific genetic marker is more likely to develop a given illness than another person without the same marker. It should also be consider that in this century most drugs developed for the treatment of cancer are "targeted drugs" forward molecular targets and its effect mainly depends on genetic variants that may be present in the tumor. 
Latin America is a region where its populations have different phenotypic characteristics due to the great interracial mixing. Population mixing; consequently, determines an important genetic flow leading to the appearance of complex characteristics influenced by given geographic and environmental factors that allow individuals to get adapted to the region where they live. These evolving changes, most of them subtle, establish a profile that could help to develop pharmacogenomic therapies on populations and individuals in order to take control of diseases, toxicity, and economic investment [35].

Scientists from different research, centers, and hospitals in Latin America have published dozens of articles in SCOPUS database. These articles focus on the population studies of different genes involved in the risk to develop different types of cancer.

Among the most distinguished research, the polymorphisms in the CYP1A1, GSTM1, TP53, CYP2E1 and EGFR genes were significant in lung cancer in Latin Americans $(p<0.05)$ [78-81], as well as in Caucasians and Asians (Table 2) [82-88]. Mutations in the BRCA1/2 and MTHFR genes in Latin Americans were associated with breast and ovarian cancer [89-103], also observed in Asians and Caucasians [104-107]. Mutations in the CYP1A1, GSTM1, MTHFR, SRD5A2, AR, and GSTA1 genes were relevant in prostate cancer in Latin Americans [108-112], also determined in Caucasians and Asians [113-121]. The IL-1, TP53, WNT, 8q24 region and IL-8 genes were consistent with gastric cancer in Latin Americans [122-126], as well as in some Asians and Caucasians [127-130]. The CDKN2A and $M C 1 R$ genes were related with myeloma in Latin Americans [131], as well as in Caucasians [132,133]. Polymorphisms in the GPX1, GST and NQO1 genes were suitable with bladder cancer [134,135], as well as in Caucasians and Asians [136-139]. Mutations in the CCND1 and TP53 genes were significant in colorectal cancer [140,141], also observed in Caucasians and Asians [142-145]. Gene alterations in GSTM1 were associated with larynx cancer en Latin Americans [146], as well as in Asians $[147,148]$. Mutations in the CYP1A1 and GSTM1 genes were relevant in oral cancer in Latin Americans [149], also detected in Asians [150-152]. The hRAD54, hMSH2, ABCB1, ABCC5, COL18A1, and SLC19A1 genes were consistent with lymphoma and leukemia in Latin Americans [153-156], as well as some Caucasians and Asians [157-160]. The RB1 gene was related with retinoblastoma in Latin Americans [161,162], and the TNF $\alpha$ and TP53 genes with cervical cancer [163-168].

Table 2. Genotyping studies related with several types of cancers in human populations worldwide.

\begin{tabular}{|c|c|c|c|c|c|}
\hline \multirow{2}{*}{ Disease } & \multirow{2}{*}{ Gene } & \multicolumn{3}{|c|}{ Human Populations } & \multirow{2}{*}{ Reference } \\
\hline & & Latin American (Country) & Caucasian * & Asian * & \\
\hline \multirow{5}{*}{ Lung cancer } & CYP1A1 & $\sqrt{ }($ Chile $)$ & $\sqrt{ }$ & $\sqrt{ }$ & {$[78,83,84]$} \\
\hline & GSTM1 & $\sqrt{ }$ (Chile) & $\sqrt{ }$ & $\sqrt{ }$ & {$[78,83,85]$} \\
\hline & TP53 & $\sqrt{ }$ (Chile) & $\sqrt{ }$ & $\sqrt{ }$ & {$[79,86,87]$} \\
\hline & CYP2E1 & $\sqrt{ }$ (Brazil) & $\varnothing$ & $\varnothing$ & {$[80,88]$} \\
\hline & EGFR & $\sqrt{ }$ (Ecuador) & $\sqrt{ }$ & $\sqrt{ }$ & {$[81,82]$} \\
\hline \multirow{3}{*}{$\begin{array}{c}\text { Breast } \\
\text { cancer/ovarian } \\
\text { cancer }\end{array}$} & $B R C A 1$ & $\begin{array}{c}\sqrt{ } \text { (Chile, Venezuela, } \\
\text { Colombia, Mexico, Argentina, } \\
\text { Brazil, Puerto Rico, Uruguay, } \\
\text { Peru, The Bahamas) }\end{array}$ & $\sqrt{ }$ & $\sqrt{ }$ & [89-102,104,105] \\
\hline & $B R C A 2$ & $\begin{array}{c}\sqrt{ } \text { (Chile, Venezuela, } \\
\text { Colombia, Mexico, Argentina, } \\
\text { Brazil, Puerto Rico, Uruguay, } \\
\text { Peru, The Bahamas) }\end{array}$ & $\sqrt{ }$ & $\sqrt{ }$ & [89-102,104,105] \\
\hline & MTHFR & $\sqrt{ }$ (Ecuador) & $\varnothing$ & $\sqrt{ }$ & {$[103,106,107]$} \\
\hline \multirow{6}{*}{ Prostate cancer } & CYP1A1 & $\sqrt{ }$ (Chile) & $\varnothing$ & $\sqrt{ }$ & {$[108,113]$} \\
\hline & GSTM1 & $\sqrt{ }$ (Chile) & $\varnothing$ & $\varnothing$ & {$[108,114]$} \\
\hline & MTHFR & $\sqrt{ }$ (Ecuador) & $\sqrt{ }$ & $\sqrt{ }$ & {$[109,115]$} \\
\hline & SRD5A2 & $\sqrt{ }$ (Ecuador) & $\sqrt{ }$ & $\varnothing$ & {$[110,116,117]$} \\
\hline & $A R$ & $\sqrt{ }$ (Ecuador) & $\sqrt{ }$ & $\sqrt{ }$ & {$[111,118,119]$} \\
\hline & GSTA1 & $\sqrt{ }($ Brazil $)$ & $\sqrt{ }$ & $\sqrt{ }$ & {$[96,120,121]$} \\
\hline
\end{tabular}


Table 2. Cont.

\begin{tabular}{|c|c|c|c|c|c|}
\hline \multirow{2}{*}{ Disease } & \multirow{2}{*}{ Gene } & \multicolumn{3}{|c|}{ Human Populations } & \multirow{2}{*}{ Reference } \\
\hline & & Latin American (Country) & Caucasian * & Asian * & \\
\hline \multirow{5}{*}{ Gastric cancer } & $I L-1$ & $\sqrt{ }($ Venezuela $)$ & $\sqrt{ }$ & $\varnothing$ & {$[122,127]$} \\
\hline & TP53 & $\sqrt{ }$ (Venezuela) & $\sqrt{ }$ & $\sqrt{ }$ & {$[123,128]$} \\
\hline & WNT & $\sqrt{ }$ (Venezuela) & - & - & {$[124]$} \\
\hline & $8 q 24$ & $\sqrt{ }$ (Venezuela) & $\sqrt{ }$ & $\sqrt{ }$ & {$[125,129]$} \\
\hline & $I L-8$ & $\sqrt{ }($ Brazil $)$ & $\varnothing$ & $\sqrt{ }$ & {$[126,130]$} \\
\hline \multirow{2}{*}{ Melanoma } & CDKN2A & $\begin{array}{c}\sqrt{ } \text { (Chile, Mexico, Argentina, } \\
\text { Brazil, Uruguay) }\end{array}$ & $\sqrt{ }$ & - & {$[131,132]$} \\
\hline & $M C 1 R$ & $\begin{array}{c}\sqrt{ }(\text { Chile, Mexico, Argentina, } \\
\text { Brazil, Uruguay })\end{array}$ & $\sqrt{ }$ & - & {$[131,133]$} \\
\hline \multirow{3}{*}{ Bladder cancer } & GPX1 & $\sqrt{ }$ (Ecuador) & $\sqrt{ }$ & $\sqrt{ }$ & {$[134,136,137]$} \\
\hline & GST & $\sqrt{ }($ Argentina $)$ & $\sqrt{ }$ & $\sqrt{ }$ & {$[135,138]$} \\
\hline & NQO1 & $\sqrt{ }$ (Argentina) & $\varnothing$ & $\sqrt{ }$ & {$[135,139]$} \\
\hline \multirow{2}{*}{$\begin{array}{l}\text { Colorectal } \\
\text { cancer }\end{array}$} & CCND1 & $\sqrt{ }$ (Ecuador) & $\sqrt{ }$ & $\sqrt{ }$ & {$[140,142,143]$} \\
\hline & TP53 & $\sqrt{ }$ (Argentina) & $\varnothing$ & $\sqrt{ }$ & {$[141,144,145]$} \\
\hline Larynx cancer & GSTM1 & $\sqrt{ }($ Chile $)$ & $\varnothing$ & $\sqrt{ }$ & [146-148] \\
\hline \multirow{2}{*}{ Oral cancer } & CYP1A1 & $\sqrt{ }($ Chile $)$ & $\varnothing$ & $\sqrt{ }$ & [141-143] \\
\hline & GSTM1 & $\sqrt{ }$ (Chile) & $\varnothing$ & $\sqrt{ }$ & {$[149,150,152]$} \\
\hline \multirow{5}{*}{$\begin{array}{l}\text { Lymphoma/ } \\
\text { leukemia }\end{array}$} & $h R A D 54$ & $\sqrt{ }$ (Ecuador) & - & - & [153] \\
\hline & hMSH2 & $\sqrt{ }$ (Ecuador) & $\sqrt{ }$ & $\varnothing$ & {$[154,157,158]$} \\
\hline & $A B C B 1 / 5$ & $\sqrt{ }($ Mexico $)$ & $\sqrt{ }$ & $\sqrt{ }$ & {$[155,156,159,160]$} \\
\hline & COL18A1 & $\sqrt{ }($ Mexico) & - & - & [156] \\
\hline & SLC19A1 & $\sqrt{ }($ Mexico $)$ & - & - & [156] \\
\hline Retinoblastoma & $R B 1$ & $\sqrt{ }$ (Ecuador) & - & $\sqrt{ }$ & {$[161,162]$} \\
\hline \multirow{2}{*}{ Cervical cancer } & $T N F \alpha$ & $\sqrt{ }$ (Argentina) & $\sqrt{ }$ & $\sqrt{ }$ & {$[163,165,166]$} \\
\hline & TP53 & $\sqrt{ }($ Brazil) & $\sqrt{ }$ & $\sqrt{ }$ & {$[164,167,168]$} \\
\hline
\end{tabular}

$\sqrt{ }$ Significant, $\varnothing$ Non-significant, - Not found, * Meta-analysis studies.

All these researches have determined the association of different genetic variants with the highest risk to develop different types of cancer in the Latin American populations. These results allow the understanding of the genome both at population and individual level in the best possible manner turning this a relevant step for the development (Table 2) (Figure 2).

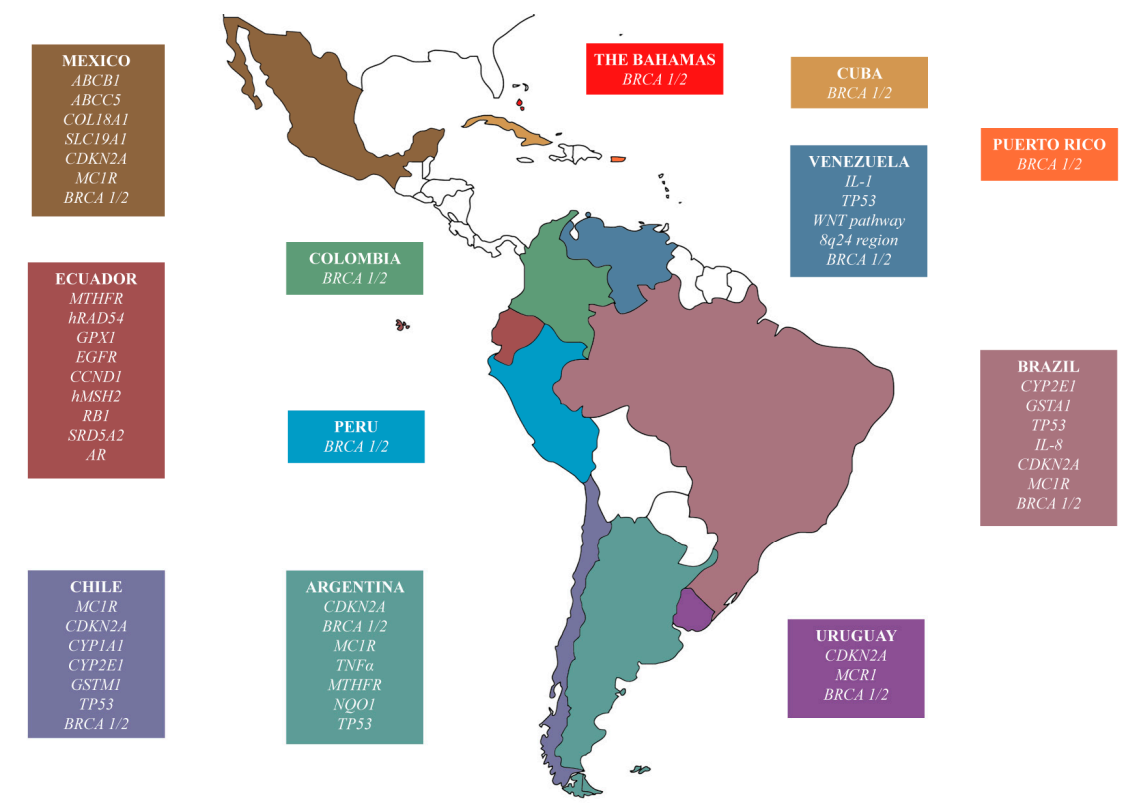

Figure 2. Cancer associated genes studied by country in Latin America. 


\section{Conclusions}

This is a transformative time for cancer therapy. The feasibility of establishing the detailed molecular portraits of individual cancers, even at the point of care, is no longer the primary obstacle to progress. Similarly, new highly potent and selective purpose-built inhibitors are being developed at a time when our understanding of actionable mutations in cancer genomes is improving steadily, resulting in continuous erosion of the market share of what has been called the undruggable genome [169]. Over the last decade, pieces of research in silico and experiments to detect somatic and germline alterations across tumor genomes have been conducted. The last progress in DNA sequencing technologies and high inter-tumor heterogeneity has generated results that are difficult to understand to identify the genes and pathways involved in tumorigenic process. Consequently, new customized medicine strategies will make it possible to improve targeted therapies against the drivers of cancer and this way, to improve patients' quality of life [170].

The implementation of pharmacogenomics in health policies conveys many benefits to patients who suffer from different types of cancer. There are several projects in charge of analyzing genomes, finding DNA elements, genes and genetic variations that affect health and disease, such as The Cancer Genome Atlas Network, the 1000 Genomes Project, the International HapMap Project, and the ENCODE Project [34,171-173]. Nevertheless, most of the samples analyzed in these projects belong to European, Asian, North American, and African populations, being the genetic participation and characterization in Latin American populations very limited [34,171-173]. The HapMap project is one of the first and largest efforts to characterize germline variant frequencies across racial populations and did not have any Latin American or South American populations (only a Mexican population in the United States) [172]. The 1000 Genomes Project (phase 3) has analyzed patients from Mexico, Colombia, Peru, and Puerto Rico [34].

The capacity to map and understand human genome has been a great success in cancer research. Starting from the analysis of the somatic and germline genomes, it is possible to establish an efficient anticancer therapy. The germline genome is involved in determining drug toxicity and exposure. The somatic genome may predict tumor behavior if treated (efficacy prediction) or untreated (prognosis) [5]. The pioneering example of molecularly driven cancer medicine was the development and use of the kinase inhibitor imatinib for the treatment of chronic myelogenous leukemias that harbor the BCR-ABL1 balanced chromosomal translocation [169]. Similarly, the advent of HER2-targeted therapies for the treatment of women with newly diagnosed metastatic HER2-positive breast cancer has radically changed the outcome of what was until recently the most lethal form of breast cancer [169].

Worldwide, there are clear guidelines for the use of pharmacogenomics published by the Canadian Pharmacogenomics Network for Drug Safety (CPNDS), the Royal Dutch Association for the Advancement of Pharmacy (DPWG), and the Clinical Pharmacogenetics Implementation Consortium (CPIC) [62-64]. For instance, simvastatin is effective in patients with the SCLO1B1 T37041C polymorphism; thioguanine is effective in individuals with the TPMT*2, $* 3 \mathrm{~A}, * 3 \mathrm{C}$ and $* 4 \mathrm{~A}$ polymorphisms; atazanavir and irinotecan are effective in patients with the UGT1A1*28 polymorphism; and amitriptyline, carvedidol, doxepin, haloperidol, olanzapine, paroxetine and venlafaxine are effective in individuals with the CYP2D6 polymorphism [62-64]. Regarding allele frequencies for these clinically relevant germline polymorphisms, Latin American countries (Colombia, Mexico, Peru, Puerto Rico, and Argentina) have similar frequencies in their alleles in contrast with Caucasian countries (Spain, England, Scotland, Finland, Italy and United States), and Asian countries (China, Bangladesh, Japan and Vietnam) [34,172].

The genotyping studies performed in 12 Latin American countries revealed 26 significant cancer driver genes implicated in 12 cancer types, such as lung, breast, ovarian or colorectal cancer. Many of these genes were significant in Latin America countries but not Caucasian or Asian populations. For instance, CYP2E1 and GSTM1 were significant in Brazil and Chile, respectively, but not in Caucasians or Asians. MTHFR was significant in Ecuador, but not in Caucasians. IL-1 was significant in Venezuela, but not in Asians (please see Table 2 for details) $[80,88,103,106]$. 
The progress in pharmacogenomics worldwide and the implementation of knowledge and techniques in clinical practice will make it possible to overcome the barriers found in Latin America. For instance, it is possible to develop regional pharmacogenomics guidelines to create health institutions in charge of developing pharmacogenetic tests, to improve health care systems by promoting the progress on pharmacogenomics, to invest in pharmacogenomics variability in Latin American populations for implementation of gene/drug pairs, to implement electronic records information of patients, and to improve economic, ethical, legal and social implications. Likewise, these goals should include ethnic comparison of pharmacogenomic profiles, gene expression, and regulation; the impact of polymorphism on phenotype; metabolic profiles of patients with a given drug; and relevant environmental factors that influence drug response. Therefore, the main idea is to accomplish the five " $R$ " for drug therapy: "the Right dose of the Right drug for the Right indication in the Right patient at the Right time" [65].

Acknowledgments: We thank to the Latin American Society of Pharmacogenomics and Personalized Medicine (SOLFAGEM) by sponsoring this article (www.solfagem.org). This work was partly financed by the grant Fondecyt 1140434, Chile.

Conflicts of Interest: The authors declare no conflict of interest.

\section{References}

1. Sierra, M.; Forman, D. Cancer in Central and South America: Methodology. Cancer Epidemiol. 2016, 44, S11-S22. [CrossRef] [PubMed]

2. McLeod, H.L. Cancer pharmacogenomics: Early promise, but concerned effort needed. Science 2013, 339, 1563-1566. [CrossRef] [PubMed]

3. Gerlinger, M.; Rowan, A.J.; Horswell, S.; Larkin, J.; Endesfelder, D.; Gronroos, E.; Martinez, P.; Matthews, N.; Stewart, A.; Tarpey, P.; et al. Intratumor heterogeneity and branched evolution revealed by multiregion sequencing. N. Engl. J. Med. 2013, 366, 883-892. [CrossRef] [PubMed]

4. Wurth, L.; Panagiotis, P.; Olmeda, D.; Bley, N.; Calvo, G.; Guerrero, S.; Cerezo-Wallis, D.; Martinez-Useros, J.; García-Fernández, M.; Hüttelmaier, S.; et al. UNR/CSDE1 drives a post-transcriptional program to promote melanoma invasion and metastasis. Cancer Cell 2016, 30, 694-707. [CrossRef] [PubMed]

5. Hertz, D.; McLeod, H.L. Use of pharmacogenetics for predicting cancer prognosis and treatment exposure, response and toxicity. J. Hum. Genet. 2013, 58, 346-352. [CrossRef] [PubMed]

6. Ma, B.B.; Hui, E.P.; Mok, T.S. Population-based differences in treatment outcome following anticancer drug therapies. Lancet Oncol. 2010, 11, 75-84. [CrossRef]

7. Collins, D.C.; Sundar, R.; Lim, J.S.J.; Yap, T.A. Towards precision medicine in the clinic: From biomarker discovery to novel therapeutics. Trends Pharmacol. Sci. 2016. [CrossRef] [PubMed]

8. Rocco, G.; Morabito, A.; Leone, A.; Muto, P.; Fiore, F.; Budillon, A. Management of non-small cell lung cancer in the era of personalized medicine. Int. J. Biochem. Cell Biol. 2016, 78, 173-179. [CrossRef] [PubMed]

9. Tan, D.S.W.; Mok, T.S.K.; Rebbeck, T.R. Cancer genomics: Diversity and disparity across ethnicity and geography. J. Clin. Oncol. 2016, 34, 91-101. [CrossRef] [PubMed]

10. Chen, F.; Zhang, Y.; Parra, E.; Rodriguez, J.; Behrens, C.; Akbani, R.; Lu, Y.; Kurie, J.M.; Ginnons, D.L.; Mills, G.B.; et al. Multiplatform-based molecular subtypes of non-small-cell lung cancer. Oncogene 2016. [CrossRef] [PubMed]

11. Engstrom, P.F.; Arnoletti, J.P.; Benson, A.B.; Chen, Y.J.; Choti, M.A.; Cooper, H.S.; Covey, A.; Dilawari, R.A.; Early, D.S.; Enzinger, P.C.; et al. NCCN clinical practice guidelines in oncology: Colon cancer. J. Natl. Compr. Cancer Netw. 2009, 7, 778-831.

12. Grothey, A.; Allegra, C.J. Antiangiogenesis therapy in the treatment of metastatic colorectal cancer. Ther. Adv. Med. Oncol. 2012, 4, 301-319. [CrossRef] [PubMed]

13. Adams, R.; Meade, A.; Wasan, H.; Griffiths, G.; Maughan, T. Cetuximab therapy in first-line metastatic colorectal cancer and intermittent palliative chemotherapy: Review of the COIN trial. Expert Rev. Anticancer Ther. 2008, 8, 1237-1245. [CrossRef] [PubMed] 
14. Amado, R.G.; Wolf, M.; Peeters, M.; van Cutsem, E.; Siena, S.; Freeman, D.J.; Juan, T.; Sikorski, R.; Suggs, S.; Radinsky, R.; et al. Wild-type KRAS is required for panitumumab efficacy in patients with metastatic colorectal cancer. J. Clin. Oncol. 2008, 26, 1626-1634. [CrossRef] [PubMed]

15. Karapetis, C.S.; Khambata-Ford, S.; Jonker, D.J.; O'Callaghan, C.J.; Tu, D.; Tebbutt, N.C.; Simen, R.J.; Chalchal, H.; Shapiro, J.D.; Robitaille, S.; et al. K-Ras mutations and benefit from cetuximab in advanced colorectal cancer. N. Engl. J. Med. 2008, 359, 1757-1765. [CrossRef] [PubMed]

16. Barbacid, M. Ras genes. Annu. Rev. Biochem. 1987, 56, 779-827. [CrossRef] [PubMed]

17. Macara, I.G.; Lounsbury, K.M.; Richards, S.A.; McKiernan, C.; Bar-Sagi, D. The Ras superfamily of GTPases. FASEB J. 1996, 10, 625-630. [PubMed]

18. Cárdenas-Ramos, S.G.; Alcázar-González, G.; Reyes-Cortés, L.M.; Torres-Grimaldo, A.A.; Calderón-Garcidueñas, A.L.; Morales-Casas, J.; Flores-Sánchez, P.; de León-Escobedo, R.; Gómez-Díaz, A.; Moreno-Bringas, C.; et al. The frequency and type of K-RAS mutations in Mexican patients with colorectal cancer. Am. J. Clin. Oncol. 2014. [CrossRef] [PubMed]

19. Rodenhuis, S.; Wetering, M.; Mooi, W.; Evers, S.; Zandwijk, N.; Bos, J. Mutational activation of the K-Ras oncogene. N. Engl. J. Med. 1987, 317, 929-935. [CrossRef] [PubMed]

20. Zocche, D.; Ramirez, C.; Fontao, F.; Costa, L.; Redal, M. Global impact of KRAS mutation patterns in FOLFOX treated metastatic colorectal cancer. Front. Genet. 2015, 6, 116. [CrossRef] [PubMed]

21. Sameer, A.S.; Chowdhri, N.A.; Abdullah, S.; Shah, Z.A.; Siddiqi, M.A. Mutation pattern of K-Ras gene in colorectal cancer patients of Kashmir: A report. Indian J. Cancer 2009, 46, 219-225. [PubMed]

22. Elsamany, S.A.; Alzahrani, A.S.; Mohamed, M.M.; Elmorsy, S.A.; Zekri, J.E.; Al-Shehri, A.S.; Haggag, R.M.; El Taani, H.A. Clinico-pathological patterns and survival outcome of colorectal cancer in young patients: Western Saudi Arabia experience. Asian Pac. J. Cancer Prev. 2014, 15, 5239-5243. [CrossRef] [PubMed]

23. Schubbert, S.; Shannon, K.; Bollag, G. Hyperactive Ras in developmental disorders and cancer. Nat. Rev. Cancer 2007, 7, 295-308. [CrossRef] [PubMed]

24. De Roock, W.; de Vriendt, V.; Normanno, N.; Ciardiello, F.; Tejpar, S. KRAS, BRAF, PIK3CA, and PTEN mutations: Implications for targeted therapies in metastatic colorectal cancer. Lancet Oncol. 2011, 12, 594-603. [CrossRef]

25. Douillard, J.Y.; Olineret, K.S.; Siena, S.; Tabernero, J.; Burkes, R.; Barugel, M.; Humblet, Y.; Bodoky, G.; Cunningham, D.; Jassem, J.; et al. Panitumumab-FOLFOX4 treatment and Ras mutations in colorectal cancer. N. Engl. J. Med. 2013, 369, 1023-1034. [CrossRef] [PubMed]

26. Akbani, R.; Akdemir, K.C.; Aksoy, B.A.; Albert, M.; Ally, A.; Amin, S.B.; Arachchi, H.; Arora, A.; Auman, J.T.; Ayala, B.; et al. Genomic classification of cutaneous melanoma. Cell 2015, 161, 1681-1696. [CrossRef] [PubMed]

27. Alioto, T.; Buchhalter, I.; Derdak, S.; Hutter, B.; Eldridge, M.; Hoving, E.; Heisler, L.E.; Beck, T.A.; Simpson, J.T.; Tonon, L.; et al. A comprehensive assessment of somatic mutation detection in cancer using whole-genome sequencing. Nat. Commun. 2015, 6, 10001. [CrossRef] [PubMed]

28. International Cancer Genome Consortium; Hudson, T.; Anderson, W.; Artez, A.; Barker, A.; Bell, C.; Bernabé, R.R.; Bhan, M.K.; Calvo, F.; Eerola, I.; et al. International network of cancer genome projects. Nature 2010, 464, 993-998. [CrossRef] [PubMed]

29. Carr, D.F.; Alfirevic, A.; Pirmohamed, M. Pharmacogenomics: Current state-of-the-art. Genes 2014, 5, 430-443. [CrossRef] [PubMed]

30. Relling, M.V.; Evans, W.E. Pharmacogenomics in the clinic. Nature 2015, 526, 343-350. [CrossRef] [PubMed]

31. Johnson, J.A.; Cavallari, L.H. Pharmacogenetics and cardiovascular disease-Implications for personalized medicine. Pharmacol. Rev. 2013, 65, 987-1009. [CrossRef] [PubMed]

32. Abedon, S.T. Phage therapy: Eco-physiological pharmacology. Scientifica 2014, 2014, 581639. [CrossRef] [PubMed]

33. Nuchnoi, P.; Nantakomol, D.; Chumchua, V.; Plabplueng, C.; Isarankura-Na-Ayudhya, C. The identification of functional non-synonymous SNP in human ATPbinding cassette (ABC), subfamily member 7 gene: Application of bioinformatics tools in biomedicine. J. Bioanal. Biomed. 2011, 3, 26-31. [CrossRef]

34. The 1000 Genomes Project Consortium. A global reference for human genetic variation. Nature 2015, 526, 68-74.

35. Paz-y-Miño, C.; López-Cortés, A. Genética Molecular y Citogenética Humana: Fundamentos, Aplicaciones e Investigaciones en el Ecuador, 1st ed.; Yachay EP: Quito, Ecuador, 2014; p. 400. 
36. Wiwanitkit, V. Possible single nucleotide polymorphism (SNP) in the nucleic sequence of a-kinase-anchoring protein 9. J. Proteom. Bioinform. 2008, 1, 227-229. [CrossRef]

37. Katara, P. Single nucleotide polymorphism and its dynamics for pharmacogenomics. Interdiscip. Sci. Comput. Life Sci. 2014, 6, 85-92. [CrossRef] [PubMed]

38. Kumar, G.M.; Prakash, N.; Pragya, Ch.; Krishna, M. Computational analysis of SNPs in $10 \mathrm{~kb}$ region of human chromosome 1. J. Comput. Sci. Syst. Biol. 2011, 4, 33-34. [CrossRef]

39. Huang, T.; Shu, Y.; Cai, Y.D. Genetic differences among ethnic groups. BMC Genom. 2015, 16, 1093. [CrossRef] [PubMed]

40. Reimer, T.; Kempert, S.; Gerber, B.; Hans-Jürgen, T.; Hartmann, S.; Koczan, D. SLCO1B1*5 polymorphism (rs4149056) is associated with chemotherapy-induced amenorrhea in premenopausal women with breast cancer: A prospective-cohort study. BMC Cancer 2016, 16, 337. [CrossRef] [PubMed]

41. König, J. Pharmacogenomics of human OATP transporters. Arch. Pharmacol. 2006, 372, 432-443. [CrossRef] [PubMed]

42. Radtke, S.; Zolk, R.; Paulides, R.; Zimmermann, M.; Möricke, A.; Stanulla, M.; Schrappe, M.; Langer, T. Germline genetic variations in methotrexate candidate genes are associated with pharmacokinetics, toxicity, and outcome in childhood acute lymphoblastic leukemia. Blood 2013, 121, 5145-5153. [CrossRef] [PubMed]

43. Ramsey, L.; Johnson, S.; Caudle, K.; Haidar, C.; Voora, D.; Wilke, R.; Maxwell, W.; McLeod, H.; Krauss, R.; Roden, D.; et al. The clinical pharmacogenetics implementation consortium guideline for SLCO1B1 and simvastatin-induced myopathy: 2014 update. Clin. Pharmacol. Ther. 2014, 96, 423-428. [CrossRef] [PubMed]

44. Ramsey, L.; Panetta, J.; Smith, C.; Yang, W.; Fan, Y.; Winick, N.; Martin, P.; Cheng, C.; Devidas, M.; Pui, C.; et al. Genome-wide study of methotrexate clearance replicates SLCO1B1. Blood 2013, 121, 898-904. [CrossRef] [PubMed]

45. Ramsey, L.; Bruun, G.; Yang, W.; Treviño, L.; Vattathil, S.; Scheet, P.; Cheng, C.; Rosner, G.; Giacomini, K.; Fan, Y.; et al. Rare versus common variants in pharmacogenetics: SLCO1B1 variation and methotrexate disposition. Genome Res. 2012, 22, 1-8. [CrossRef] [PubMed]

46. Grem, J.L. 5-Fluorouracil: Forty-plus and still ticking. A review of its preclinical and clinical development. Investig. New Drugs 2000, 18, 299-313. [CrossRef]

47. Leichman, C.G.; Lenz, H.J.; Leichman, L.; Danenberg, K.; Baranda, J.; Groshen, S.; Boswell, W.; Metzger, R.; Tan, M.; Denenberg, P.V. Quantitation of intratumoral thymidylate synthase expression predicts for disseminated colorectal cancer response and resistance to protracted-infusion fluorouracil and weekly leucovorin. J. Clin. Oncol. 1997, 15, 3223-3229. [CrossRef] [PubMed]

48. Pullarkat, S.T.; Stoehlmacher, J.; Ghaderi, V.; Xiong, Y.P.; Ingles, S.A.; Sherrod, A.; Warren, R.; Tsao-Wei, D.; Groshen, S.; Lenz, H.J. Thymidylate synthase gene polymorphism determines response and toxicity of 5-FU chemotherapy. Pharmacogenom. J. 2001, 1, 65-70. [CrossRef]

49. Niedzwiecki, D.; Hasson, R.; Lenz, H.; Ye, C.; Redston, M.; Ogino, S.; Fuchs, C.; Compton, C.; Mayer, R.; Goldberg, R.; et al. A study of thymidylate synthase expression as a biomarker for resectable colon cancer: Alliance (cancer and leukemia group B) 9581 and 89803. Oncologist 2016. [CrossRef] [PubMed]

50. Yang, J.; Cai, L.; Huang, H.; Liu, B.; Wu, Q. Genetic variations and haplotype diversity of the UGT1 gene cluster in the Chinese population. PLoS ONE. 2012, 7, e33988. [CrossRef] [PubMed]

51. Kupiec, T.; Raj, V.; Vu, N. Pharmacogenomics for the forensic toxicologist. J. Anal. Toxicol. 2006, 30, 65-72. [CrossRef] [PubMed]

52. Lee, W.; Lockhart, A.C.; Kim, R.B.; Rothenberg, M.L. Cancer pharmacogenomics: Powerful tools in cancer chemotherapy and drug development. Oncologist 2005, 10, 104-111. [CrossRef] [PubMed]

53. Evans, W.E.; Horner, M.; Chu, Y.Q.; Kalwinsky, D.; Roberts, W.M. Altered mercaptopurine metabolism, toxic effects, and dosage requirement in a thiopurine methyltransferase-deficient child with acute lymphocytic leukemia. J. Pediatr. 1991, 119, 985-989. [CrossRef]

54. Laróvere, L.; de Kremer, R.; Lambooy, L.; de Abreu, R. Genetic polymorphism of thiopurine S-methyltransferase in Argentina. Ann. Clin. Biochem. 2003, 40, 388-393. [CrossRef] [PubMed]

55. Collie-Duguid, E.S.; Pritchard, S.C.; Powrie, R.H.; Sludden, J.; Collier, D.A.; Li, T.; McLeod, H.L. The frequency and distribution of thiopurine methyltransferase alleles in Caucasian and Asian populations. Pharmacogenetics 1999, 9, 37-42. [CrossRef] [PubMed] 
56. Yates, C.R.; Krynetski, E.Y.; Loennechen, T.; Fessing, M.Y.; Tai, H.L.; Pui, C.H.; Relling, M.V.; Evans, W.E. Molecular diagnosis of thiopurine $S$-methyltransferase deficiency: Genetic basis for azathioprine and mercaptopurine intolerance. Ann. Intern. Med. 1997, 126, 608-614. [CrossRef] [PubMed]

57. Rothenberg, M.L.; Kuhn, J.G.; Burris, H.A.; Nelson, J.; Eckardt, J.R.; Tristan-Morales, M.; Hilsenbeck, S.G.; Weiss, G.R.; Smith, L.S.; Rodríguez, G.I. Phase I and pharmacokinetic trial of weekly CPT-11. J. Clin. Oncol. 1993, 11, 2194-2204. [CrossRef] [PubMed]

58. Gupta, E.; Lestingi, T.M.; Mick, R.; Ramirez, J.; Vokes, E.E.; Ratain, M.J. Metabolic fate of irinotecan in humans: Correlation of glucuronidation with diarrhea. Cancer Res. 1994, 54, 3723-3725. [PubMed]

59. Bosma, P.J.; Chowdhury, J.R.; Bakker, C.; Gantla, S.; de Boer, A.; Oostra, B.A.; Lindhout, D.; Tytgat, G.N.; Jansen, P.L.; Oude Elfernik, R.P. The genetic basis of the reduced expression of bilirubin UDP-glucuronosyltransferase 1 in Gilbert's syndrome. N. Engl. J. Med. 1995, 333, 1171-1175. [CrossRef] [PubMed]

60. Innocenti, F.; Undevia, S.D.; Iyer, L.; Chen, P.X.; Das, S.; Kocherginsky, M.; Karrison, T.; Janisch, L.; Ramírez, J.; Rudin, C.M.; et al. Genetic variants in the UDP-glucuronosyltransferase $1 A 1$ gene predict the risk of severe neutropenia of irinotecan. J. Clin. Oncol. 2004, 22, 1382-1388. [CrossRef] [PubMed]

61. Evans, W.E. Pharmacogenomics: Marshalling the human genome to individualise drug therapy. Gut 2003, 52, ii10-ii18. [CrossRef] [PubMed]

62. Relling, M.; Klein, T. CPIC: Clinical Pharmacogenetics Implementation Consortium of the pharmacogenomics research network. Clin. Pharmacol. Ther. 2011, 89, 464-467. [CrossRef] [PubMed]

63. Swen, J.; Nijenhuis, M.; de Boer, A.; Grandia, L.; Maitland-van der Zee, A.; Mulden, H.; Ronger, G.; van Schaik, R.; Schalekamp, T.; Touw, D.; et al. Pharmacogenomics: From bench to byte-An update of guidelines. Clin. Pharmacol. Ther. 2011, 89, 662-673. [CrossRef] [PubMed]

64. Ross, C.; Visscher, H.; Sistonen, J.; Brunham, L.; Pussegoda, K.; Loo, T.; Rieder, M.; Koren, G.; Carleston, B.; Hyden, M.; et al. The Canadian Pharmacogenomics Network for Drug Safety: A model for safety pharmacology. Thyroid 2010, 20, 681-687. [CrossRef] [PubMed]

65. Quiñones, L.A.; Lavanderos, M.A.; Cayun, J.P.; García-Martín, E.; Agúndez, J.A.; Cáceres, D.D.; Roco, A.M.; Morales, J.E.; Herrera, L.; Encina, G.; et al. Perception of the usefulness of drug/gene pairs and barriers for pharmacogenomics in Latin America. Curr. Drug Metab. 2014, 15, 202-208. [CrossRef] [PubMed]

66. Atun, R.; de Andrade, L.O.M.; Almeida, G.; Cotlear, D.; Dmytraczenko, T.; Frenz, P.; Garcia, P.; Gómez-Dantés, O.; Knaul, F.M.; Muntaner, C.; et al. Health-system reform and universal health coverage in Latin America. Lancet 2015, 385, 1230-1247. [CrossRef]

67. Goss, P.E.; Lee, B.L.; Badovinac-Crnjevic, T.; Strasser-Weippl, K.; Chavarri-Guerra, Y.; Louis, J.S.; Villarreal-Garza, C.; Unger-Saldaña, K.; Ferreyra, M.; Debiasi, M.; et al. Planning cancer control in Latin America and the Caribbean. Lancet Oncol. 2013, 14, 391-436. [CrossRef]

68. Sierra, M.; Soerjomataram, I.; Antoni, S.; Laversanne, M.; Piñeros, M.; de Vries, E.; Forman, D. Cancer patterns and trends in Central and South America. Cancer Epidemiol. 2016, 44, S23-S42. [CrossRef] [PubMed]

69. Country Profile: Human Development Indicators. United Nations Development Programme (UNDP), 2013. Available online: http:/ /hdr.undp.org/en/data/profiles / (accessed on 13 March 2017).

70. Ferlay, J.; Soerjomataram, I.; Dikshit, R.; Eser, S.; Mathers, C.; Rebelo, M.; Parkin, D.M.; Forman, D.; Bray, F. Cancer incidence and mortality worldwide: Sources, methods and major patterns in GLOBOCAN 2012. Int. J. Cancer 2015, 136, E359-E386. [CrossRef] [PubMed]

71. Forman, D.; Sierra, M. Cancer in Central and South America: Introduction. Cancer Epidemiol. 2016, 44, S3-S10. [CrossRef] [PubMed]

72. Di Sibio, A.; Abriata, G.; Forman, D.; Sierra, M. Female breast cancer in Central and South America. Cancer Epidemiol. 2016, 44, S110-S120. [CrossRef] [PubMed]

73. Sierra, M.; Soerjomataram, I.; Forman, D. Prostate cancer burden in Central and South America. Cancer Epidemiol. 2016, 44, S131-S140. [CrossRef] [PubMed]

74. Piñeros, M.; Sierra, M.; Forman, D. Descriptive epidemiology of lung cancer and current status to tobacco control measures in Central and South America. Cancer Epidemiol. 2016, 44, S90-S99. [CrossRef] [PubMed]

75. Sierra, M.; Cueva, P.; Bravo, L.E.; Forman, D. Stomach cancer burden in Central and South America. Cancer Epidemiol. 2016, 44, S62-S73. [CrossRef] [PubMed]

76. Sierra, M.; Forman, D. Burden of colorectal cancer in Central and South America. Cancer Epidemiol. 2016, 44, S74-S81. [CrossRef] [PubMed] 
77. Murillo, R.; Herrero, R.; Sierra, M.; Forman, D. Cervical cancer in Central and South America: Burden of disease and status of disease control. Cancer Epidemiol. 2016, 44, S121-S130. [CrossRef] [PubMed]

78. Quiñones, L.; Lucas, D.; Godoy, J.; Cáceres, D.; Berthou, F.; Varela, N.; Lee, K.; Acevedo, C.; Martínez, L.; Aguilera, A.M.; et al. CYP1A1, CYP2E1 and GSTM1 genetic polymorphisms. The effect of single and combined genotypes on lung cancer susceptibility in Chilean people. Cancer Lett. 2001, 174, 35-44. [CrossRef]

79. Cáceres, D.D.; Quiñones, L.A.; Schroeder, J.C.; Gil, L.D.; Irarrázabal, C.E. Association between p53 codon 72 genetic polymorphism and tobacco use and lung cancer risk. Lung 2009, 187, 110-115. [CrossRef] [PubMed]

80. Sugimura, H.; Hamada, G.S.; Suzuki, I.; Iwase, T.; Kiyokawa, E.; Kino, I.; Tsugane, S. CYP1A1 and CYP2E1 polymorphism and lung cancer, case-control study in Rio de Janeiro, Brazil. Pharmacogenetics 1995, 5, S145-S148. [CrossRef] [PubMed]

81. Paz-y-Miño, C.; López-Cortés, A.; Muñoz, M.J.; Cabrera, A.; Castro, B.; Sánchez, M.E. Incidence of the L858R and G719S mutations of the epidermal growth factor receptor oncogene in an Ecuadorian population with lung cancer. Cancer Genet. Cytogenet. 2010, 196, 201-203. [CrossRef] [PubMed]

82. Midha, A.; Dearden, S.; McCormack, R. EGFR mutation incidence in non-small-cell lung cancer of adenocarcinoma histology: A systematic review and global map by ethnicity (mutMapII). Am. J. Cancer Res. 2015, 5, 2892-2911. [PubMed]

83. Hung, RJ.; Boffeta, P.; Brockmöller, J.; Butkiewicz, D.; Cascorbi, I.; Clapper, M.; Garte, S.; Hauger, A.; Hirvonen, A.; Anttila, S.; et al. CYP1A1 and GSTM1 genetic polymorphisms and lung cancer risk in Caucasian non-smokers: A pooled analysis. Carcinogenesis 2003, 24, 875-882. [CrossRef] [PubMed]

84. Shaffi, S.; Shah, M.; Bhat, I.; Koul, P.; Ahmad, S.; Siddiqi, M. CYP1A1 polymorphisms and risk of lung cancer in the ethnic Kashmiri population. Asian Pac. J. Cancer Prev. 2009, 10, 651-656. [PubMed]

85. Lui, X.; Li, Z.; Zhang, Z.; Zhang, W.; Li, W.; Xiao, Z.; Liu, H.; Jiao, H.; Wang, Y.; Li, G. Meta-analysis of GSTM1 null genotype and lung cancer in Asians. Med. Sci. Monit. 2014, 20, 1239-1245. [CrossRef] [PubMed]

86. Wang, S.; Lan, X.; Tan, S.; Wang, S.; Li, Y. P53 codon 72 Arg/Pro polymorphism and lung cancer risk Asians: As updated meta-analysis. Tumor Biol. 2013, 34, 2511-2520. [CrossRef] [PubMed]

87. Ye, X.; Bu, Z.; Feng, J.; Peng, L.; Liao, X.; Zhu, X.; Sun, X.; Yu, H.; Yan, D.; Yan, S. Association between the TP53 polymorphisms and lung cancer risk: A meta-analysis. Mol. Biol. Rep. 2014, 41, 373-385. [CrossRef] [PubMed]

88. Ze-Tian, S.; Xin-Hu, W.; Bing, L.; Jun-shu, S.; Zhen, W.; Jing, L.; Xi-Xi, Z. CYP2E1 Rsa I/Pst I polymorphism and lung cancer susceptibility: A meta-analysis involving 10,947 subjects. J. Cell. Mol. Med. 2015, 19, 2136-2142.

89. Gonzalez-Hormazabal, P.; Gutierrez-Enriquez, S.; Gaete, D.; Reyes, J.M.; Peralta, O.; Waugh, E.; Gomez, F.; Margarit, S.; Bravo, T.; Diez, O.; et al. Spectrum of BRCA1/2 point mutations and genomic rearrangements in high-risk breast/ovarian cancer Chilean families. Breast Cancer Res. Treat. 2011, 126, 705-716. [CrossRef] [PubMed]

90. Gallardo, M.; Silva, A.; Rubio, L.; Alvarez, C.; Torrealba, C.; Salinas, M.; Tapia, T.; Faundez, P.; Palma, L.; Riccio, M.E.; et al. Incidence of BRCA1 and BRCA2 mutations in 54 Chilean families with breast/ovarian cancer, genotype-phenotype correlations. Breast Cancer Res. Treat. 2006, 95, 81-87. [CrossRef] [PubMed]

91. Lara, K.; Consigliere, N.; Pérez, J.; Porco, A. BRCA1 and BRCA2 mutations in breast cancer patients from Venezuela. Biol. Res. 2012, 45, 117-130. [CrossRef] [PubMed]

92. Hernández, J.E.; Llacuachaqui, M.; Palacio, G.V.; Figueroa, J.D.; Madrid, J.; Lema, M.; Royer, R.; Li, S.; Larson, G.; Weitzel, J.N.; et al. Prevalence of BRCA1 and BRCA2 mutations in unselected breast cancer patients from Medellín, Colombia. Hered. Cancer Clin. Pract. 2014, 12, 11. [CrossRef] [PubMed]

93. Villarreal-Garza, C.; Alvarez-Gómez, R.M.; Pérez-Plasencia, C.; Herrera, L.A.; Herzog, J.; Castillo, D.; Mohar, A.; Castro, C.; Gallardo, L.N.; Gallardo, D.; et al. Significant clinical impact of recurrent BRCA1 and BRCA2 mutations in Mexico. Cancer 2015, 121, 372-378. [CrossRef] [PubMed]

94. Solano, A.R.; Aceto, G.M.; Delettieres, D.; Veschi, S.; Neuman, M.I.; Alonso, E.; Chialina, S.; Chacón, R.D.; Renato, M.C.; Podestá, E.J. BRCA1 and BRCA2 analysis of Argentinean breast/ovarian cancer patients selected for age and family history highlights a role for novel mutations of putative south-American origin. Springerplus 2012, 25, 1-20. [CrossRef] [PubMed]

95. Gomes, M.C.; Costa, M.M.; Borojevic, R.; Monteiro, A.N.; Vieira, R.; Koifman, S.; Koifman, R.J.; Li, S.; Royer, R.; Zhang, S.; et al. Prevalence of BRCA1 and BRCA2 mutations in breast cancer patients from Brazil. Breast Cancer Res. Treat. 2007, 103, 349-353. [CrossRef] [PubMed] 
96. Rodriguez, R.C.; Esperon, A.A.; Ropero, R.; Rubio, M.C.; Rodriguez, R.; Ortiz, R.M.; Anta, J.J.; de los Rios, M.; Carnesolta, D.; del Olivera, M.C.; et al. Prevalence of BRCA1 and BRCA2 mutations in breast cancer patients from Cuba. Fam. Cancer. 2008, 7, 275-279. [CrossRef] [PubMed]

97. Dutil, J.; Colon-Colon, J.L.; Matta, J.L.; Sutphen, R.; Echenique, M. Identification of the prevalent BRCA1 and BRCA2 mutations in the female population of Puerto Rico. Cancer Genet. 2012, 205, 242-248. [CrossRef] [PubMed]

98. Dutil, J.; Golubeva, V.A.; Pacheco-Torres, A.L.; Diaz-Zabala, H.J.; Matta, J.L.; Monteiro, A.N. The spectrum of BRCA1 and BRCA2 alleles in Latin America and the Caribbean: A clinical perspective. Breast Cancer Res. Treat. 2015, 154, 441. [CrossRef] [PubMed]

99. Delgado, L.; Fernández, G.; Grotiuz, G.; Cataldi, S.; González, A.; Lluveras, N.; Heguaburu, M.; Fresco, R.; Lens, D.; Sabini, G.; et al. BRCA1 and BRCA2 germline mutations in Uruguayan breast and breast-ovarian cancer families. Identification of novel mutations and unclassified variants. Breast Cancer Res. Treat. 2011, 128, 211-218. [CrossRef] [PubMed]

100. Abugattas, J.; Llacuachaqui, M.; Allende, Y.S.; Velásquez, A.A.; Velarde, R.; Cotrina, J.; Garcés, M.; León, M.; Calderón, G.; de la Cruz, M.; et al. Prevalence of BRCA1 and BRCA2 mutations in unselected breast cancer patients from Peru. Clin. Genet. 2015, 88, 371-375. [CrossRef] [PubMed]

101. Buleje, J.L.; Huaman, F.; Guevara, M.; Acosta, O.; Pinto, J.A.; Araujo, J.; Ponce, J.; León, J.; Lizaraso, F.; Gómez, H.; et al. Detección de reordenamientos genómicos en los genes BRCA1 y BRCA2 en 16 familias peruanas con cáncer de mama mediante Amplificación de Sondas dependiente de Ligamiento Múltiple (MLPA). Carcinos 2015, 5, 34-38.

102. Akbari, M.R.; Donenberg, T.; Lunn, J.; Curling, D.; Turnquest, T.; Krill-Jackson, E.; Zhang, S.; Narod, S.A.; Hurley, J. The spectrum of BRCA1 and BRCA2 mutations in breast cancer patients in the Bahamas. Clin. Genet. 2014, 85, 64-67. [CrossRef] [PubMed]

103. López-Cortés, A.; Echeverría, C.; Oña-Cisneros, F.; Sánchez, M.E.; Herrera, C.; Cabrera-Andrade, A.; Rosales, F.; Ortiz, M.; Paz-y-Miño, C. Breast cancer risk associated with gene expression and genotype polymorphisms of the folate-metabolizing MTHFR gene: A case-control study in a high altitude Ecuadorian mestizo population. Tumor Biol. 2015, 36, 6451-6461. [CrossRef] [PubMed]

104. Hall, M.; Reid, J.; Burbidge, L.; Pruss, D.; Deffenbaugh, A.; Frye, C.; Wenstrup, R.; Ward, B.; Scholl, T.; Noll, W. BRCA1 and BRCA2 mutations in women of different ethnicities undergoing testing for hereditary breast-ovarian cancer. Cancer 2009, 115, 2222-2233. [CrossRef] [PubMed]

105. Haeyoung, K.; Doo Ho, C. Distribution of BRCA1 and BRCA2 mutations in Asian patients with breast cancer. J. Breast Cancer 2013, 16, 357-365.

106. Zhang, X.; Li, Y.; Yang, S.; Li, W. Meta-analysis on MTHFR polymorphism and lung cancer susceptibility in East Asian populations. Biomed. Rep. 2013, 1, 440-446. [PubMed]

107. Chen, L.; Lu, N.; Zhang, B.; Weng, B.; Weng, L.; Lu, J. Association between the MTHFR C677T polymorphism and gastric cancer susceptibility: A meta-analysis of 5757 cases and 8501 controls. Oncol. Lett. 2015, 10, 1159-1165. [PubMed]

108. Acevedo, C.; Opazo, J.L.; Huidobro, C.; Cabezas, J.; Iturrieta, J.; Quiñones Sepúlveda, L. Positive correlation between single or combined genotypes of CYP1A1 and GSTM1 in relation to prostate cancer in Chilean people. Prostate 2003, 57, 111-117. [CrossRef] [PubMed]

109. López-Cortés, A.; Jaramillo-Koupermann, G.; Muñoz, M.J.; Cabrera, A.; Echeverría, C.; Rosales, F.; Vivar, N.; Paz-y-Miño, C. Genetic polymorphisms in MTHFR (C677T, A1298C), MTR (A2756G) and MTRR (A66G) genes associated with pathological characteristics of prostate cancer in the Ecuadorian population. Am. J. Med. Sci. 2013, 346, 447-454. [CrossRef] [PubMed]

110. Paz-y-Miño, C.; Witte, T.; Robles, P.; Llumipanta, W.; Díaz, M.; Arévalo, M. Association among polymorphisms in the steroid $5 \alpha$-reductase type II (SRD5A2) gene, prostate cancer risk, and pathologic characteristics of prostate tumors in an Ecuadorian population. Cancer Genet. Cytogenet. 2009, 189, 71-76. [CrossRef] [PubMed]

111. Paz-y-Miño, C.; Robles, P.; Salazar, C.; Leone, P.E.; García-Cárdenas, J.M.; Naranjo, M.; López-Cortés, A. Positive association of the androgen receptor CAG repeat length polymorphism with the risk of prostate cancer. Mol. Med. Rep. 2016, 14, 1791-1798. [PubMed] 
112. Sá, R.A.; Moreira, A.D.S.; Cabello, P.H.; Ornellas, A.A.; Costa, E.B.; Matos, C.; Alves, G. Human glutathione S-transferase polymorphisms associated with prostate cancer in the Brazilian population. Int. Braz. J. Urol. 2014, 40, 463-473. [CrossRef] [PubMed]

113. Ding, G.; Xu, W.; Liu, H.; Zhang, M.; Huang, Q.; Liao, Z. CYP1A1 MspI polymorphism is associated with prostate cancer susceptibility: Evidence from a meta-analysis. Mol. Biol. Rep. 2013, 40, 3483-3491. [CrossRef] [PubMed]

114. Malik, S.; Kazmi, Z.; Fatima, I.; Shabbir, R.; Perveen, S.; Masood, N. Genetic polymorphism of GSTM1 and GSTT1 and risk of prostatic carcinoma-A Meta-analysis of 7281 prostate cancer cases and 9082 healthy controls. Asian Pac. J. Cancer Prev. 2016, 17, 2629-2635. [PubMed]

115. Chen, P.; Li, W.; Wang, J.; Jiang, Y.; Wu, P.; Chen, T.; Zheng, S. Association between MTHFR gene polymorphism (C677T, A1298C) and genetic susceptibility to prostate cancer: A meta-analysis. Genet. Mol. Res. 2015, 14, 19191-19202. [CrossRef] [PubMed]

116. Neslund-Dudas, C.; Bock, C.; Monaghan, K.; Nock, N.; Yang, N.; Yang, J.; Rundle, A.; Tang, D.; Rybicki, B. SRD5A2 and HSD3B2 polymorphisms are associated with prostate cancer risk and aggressiveness. Prostate 2007, 67, 1654-1663. [CrossRef] [PubMed]

117. Wang, C.; Tao, W.; Chen, Q.; Hu, H.; Wen, X.; Han, R. SRD5A2 V89L polymorphism and prostate cancer risk: A meta-analysis. Prostate 2010, 70, 170-178. [PubMed]

118. Gsur, A.; Preyer, M.; Haidinger, G.; Zidek, T.; Madersbacher, S.; Schatzl, G.; Marberger, M.; Vutuc, C.; Micksche, M. Polymorphic CAG repeats in the androgen receptor gene, prostate-specific antigen polymorphism and prostate cancer risk. Carcinogenesis 2002, 23, 1647-1651. [CrossRef] [PubMed]

119. Irvine, R.; Yu, M.; Ross, R.; Coetzee, G. The CAG and GGC microsatellites of the androgen receptor gene are in linkage disequilibrium in men with prostate cancer. Cancer Res. 1995, 55, 1937-1940. [PubMed]

120. Komiya, Y.; Tsukino, H.; Nakao, H.; Kuroda, Y.; Imai, H.; Katoh, T. Human glutathione S-transferase A1, T1, M1, and P1 polymorphisms and susceptibility to prostate cancer in the Japanese population. J. Cancer Res. Clin. Oncol. 2005, 131, 238-242. [CrossRef] [PubMed]

121. Ning, B.; Wang, C.; More, F.; Nowell, S.; Ratnasinghe, D.; Carter, W.; Kadlubar, F.; Coles, B. Human glutathione $S$-transferase A2 polymorphisms: Variant expression, distribution in prostate cancer cases/controls and a novel form. Pharmacogenetics 2004, 14, 35-44. [CrossRef] [PubMed]

122. Chiurillo, M.A. Role of gene polymorphisms in gastric cancer and its precursor lesions: Current knowledge and perspectives in Latin American countries. World J. Gastroenterol. 2014, 20, 4503-4515. [CrossRef] [PubMed]

123. Cañas, M.; Morán, Y.; Camargo, M.E.; Rivero, M.B.; Bohórquez, A.; Villegas, V.; Ramírez, E.; Rendón, Y.; Suárez, A.; Morales, L.; et al. TP53 codon 72 polymorphism and gastric cancer risk: A case-control study in individuals from the central-western region of Venezuela. Investig. Clin. 2009, 50, 153-161.

124. Chiurillo, M.A. Role of the Wnt/ $\beta$-catenin pathway in gastric cancer: An in-depth literature review. World J. Exp. Med. 2015, 5, 84-102. [CrossRef] [PubMed]

125. Labrador, L.; Torres, K.; Camargo, M.; Santiago, L.; Valderrama, E.; Chiurillo, M.A. Association of common variants on chromosome 8q24 with gastric cancer in Venezuelan patients. Gene 2015, 566, 120-124. [CrossRef] [PubMed]

126. Felipe, A.V.; Silva, T.D.; Pimenta, C.A.; Kassab, P.; Forones, N.M. lnterleukin-8 gene polymorphism and susceptibility to gastric cancer in a Brazilian population. Biol. Res. 2012, 45, 369-374. [CrossRef] [PubMed]

127. Camargo, M.; Mera, R.; Correa, P.; Peek, R.; Fontham, E.; Goodman, K.; Piazuelo, M.; Sicinschi, L.; Zabaleta, J.; Schneider, B. Interleukin-1 $\beta$ and interleukin-1 receptor antagonista gene polymorphisms and gastric cancer: A meta-analysis. Cancer Epidemiol. Biomark. Prev. 2006, 15, 1674-1687. [CrossRef] [PubMed]

128. Peirce, L. Gastric cancer review. J. Carcinog. 2014, 13, 14.

129. Mocellin, S.; Verdi, D.; Pooley, K.; Nitti, D. Genetic variation and gastric cancer risk: A field synopsis and meta-analysis. Gut 2015, 64, 1209-1219. [CrossRef] [PubMed]

130. Wang, J.; Pan, H.; Hu, Y.; Zhu, Y.; He, Q. Polymorphism of IL-8 in 251 allele and gastric cancer susceptibility: A meta-analysis. Dig. Dis. Sci. 2010, 55, 1818-1823. [CrossRef] [PubMed]

131. Puig, S.; Potrony, M.; Cuellar, F.; Puig-Butille, J.A.; Carrera, C.; Aguilera, P.; Nagore, E.; García-Casado, Z.; Requena, C.; Kumar, R.; et al. Characterization of individuals at high risk of developing melanoma in Latin America: Bases for genetic counseling in melanoma. Genet. Med. 2015, 18, 727-736. [CrossRef] [PubMed]

132. Hayward, N. Genetics of melanoma predisposition. Oncogene 2003, 22, 3053-3062. [CrossRef] [PubMed] 
133. Ibarrola-Villava, M.; Hu, H.-H.; Guedj, M.; Fernandez, L.; Descamps, V.; Basset-Seguin, N.; Bagot, M.; Benssussan, A.; Saiag, P.; Fargnoli, M.; et al. MC1R, SLC45A2 and TYR genetic variants involved in menaloma susceptibility in Southern European populations: Results from a meta-analysis. Eur. J. Cancer 2012, 48, 2183-2191. [CrossRef] [PubMed]

134. Paz-y-Miño, C.; Muñoz, M.J.; López-Cortés, A.; Cabrera, A.; Palacios, A.; Castro, B.; Paz-y-Miño, N.; Sánchez, M.E. Frequency of polymorphisms pro198leu in GPX-1 gene and ile58thr in MnSOD gene in the altitude Ecuadorian population with bladder cancer. Oncol. Res. 2010, 18, 395-400. [CrossRef] [PubMed]

135. Moore, L.E.; Wiencke, J.K.; Bates, M.N.; Zheng, S.; Rey, O.A.; Smith, A.H. Investigation of genetic polymorphisms and smoking in a bladder cancer case-control study in Argentina. Cancer Lett. 2004, 211, 199-207. [CrossRef] [PubMed]

136. Ichimura, Y.; Habuchi, T.; Tsuchiya, N.; Wang, L.; Oyama, C.; Sato, K.; Nishiyama, H.; Ogawa, O.; Kato, T. Increased risk of bladder cancer associated with a glutathione peroxidase 1 codon 198 variant. J. Urol. 2004, 172, 728-732. [CrossRef] [PubMed]

137. Kucukgergin, C.; Sanli, O.; Amasyah, A.; Tefik, T.; Seckin, S. Genetic variants of MnSOD and GPX1 and susceptibility to bladder cancer in a Turkish population. Med. Oncol. 2012, 29, 1928-1934. [CrossRef] [PubMed]

138. Gong, M.; Dong, W.; An, R. Glutathione S-transferase T1 polymorphism contributes to bladder cancer risk: A meta-analysis involving 50 studies. DNA Cell Biol. 2012, 31, 1187-1197. [CrossRef] [PubMed]

139. Yang, S.; Su, H.; Zhu, J.; Wang, D.; Zhu, S.; Li, S.; He, J.; Chen, Y. The association between NQO1 pro187ser polymorphism and bladder cancer susceptibility: A meta-analysis of 15 studies. PLoS ONE 2015, 10, e0116500. [CrossRef] [PubMed]

140. Paz-y-Miño, C.; Salazar, C.; Zurita, T.; López-Cortés, A.; Hidalgo, R.; Rosales, F.; Montalvo, A.; Leone, P.E. Positive association between the polymorphic variant CCND1 A870G and colorectal cancer in Ecuadorian mestizo population. J. Cancer Res. Updat. 2015, 4, 163-170. [CrossRef]

141. Pérez, L.O.; Abba, M.C.; Dulout, F.N.; Golijow, C.D. Evaluation of p53 codon 72 polymorphism in adenocarcinomas of the colon and rectum in La Plata, Argentina. World J. Gastroenterol. 2006, 12, 1426-1429. [CrossRef] [PubMed]

142. Chen, B.; Yang, P.; Zhou, Y.; Wu, X. Cyclin D1 (CCND1) G870A gene polymorphism is an ethnicity-dependent risk factor for digestive tract cancers: A meta-analysis comprising 20,271 subjects. Cancer Epidemiol. 2012, 36, 106-115. [CrossRef] [PubMed]

143. Xu, X.; Ni, X.; Yang, G.; Luo, Z.; Niu, Y.; Shen, M. CCND1 G870A polymorphism and colorectal cancer: An updated meta-analysis. Mol. Clin. Oncol. 2016, 4, 1078-1084. [CrossRef] [PubMed]

144. Liu, Y.; Qin, H.; Zhang, Y.; Shi, T.; Liu, B.; Sun, Y.; Ma, Y. P53 codon 72 polymorphism and colorectal cancer: A meta-analysis of epidemiological studies. Hepatogastroenterology 2011, 58, 1926-1929. [PubMed]

145. Economopoulos, K.; Sergentanis, T.; Zagouri, F.; Zografos, G. Association between p53 Arg72Pro polymorphism and colorectal cancer risk: A meta-analysis. Onkologie 2010, 33, 666-674. [CrossRef] [PubMed]

146. Rahal, M.; Herrera, M.J.; Quiñones, L.; Farfán, N.; Cáceres, D.; Roco, A. Frequency of CYP1A1*2a and GSTM1 gene polymorphisms in Chilean patients with squamous cell carcinoma of the larynx in relation to smoking habit: A pilot study. Rev. Otorrinolaringol. Cir. Cabeza Cuello 2013, 73, 7-16.

147. Liu, X.; Fan, Q.; Ni, L.; Liu, F.; Huang, S.; Gao, J.; Chen, B. GSTM1 null genotype is a risk factor for laryngeal cancer. Int. J. Clin. Exp. Med. 2015, 8, 7661-7666. [PubMed]

148. Zhuo, W.; Wang, Y.; Zhuo, X.; Zhu, B.; Zhu, Y.; Chen, Z. Polymorphisms of CYP1A1 and GSTM1 and laryngeal cancer risk: Evidence-based meta-analyses. J. Cancer Res. Clin. Oncol. 2009, 135, 1081-1090. [CrossRef] [PubMed]

149. Cordero, K.; Espinoza, I.; Cáceres, D.; Roco, A.; Miranda, C.; Squicciarini, V.; Santander, P.; Lee, K.; Saavedra, I.; Quiñones, L. Oral cancer susceptibility associated with the CYP1A1 and GSTM1 genotypes in Chilean individuals. Oncol. Lett. 2010, 1, 549-553. [PubMed]

150. Cha, I.-H.; Park, J.; Chung, W.; Choi, M.; Kim, H.; Park, K. Polymorphisms of CYP1A1 and GSTM1 genes and susceptibility to oral cancer. Yonsei Med. J. 2007, 48, 233-239. [CrossRef] [PubMed]

151. Xie, S.; Luo, C.; Shan, X.; Zhao, S.; He, J.; Cai, Z. CYP1A1 MspI polymorphism and the risk of oral squamous cell carcinoma: Evidence from a meta-analysis. Mol. Clin. Oncol. 2016, 4, 660-666. [CrossRef] [PubMed] 
152. Zhuo, W.; Wang, Y.; Zhuo, X.; Zhu, Y.; Wang, W.; Zhu, B.; Li, D.; Chen, Z. CYP1A1 and GSTM1 polymorphisms and oral cancer risk: Association studies via evidence-based meta-analyses. Cancer Investig. 2009, 27, 86-95. [CrossRef] [PubMed]

153. Paz-y-Miño, C.; López-Cortés, A.; Muñoz, M.J.; Castro, B.; Cabrera, A.; Sánchez, M.E. Relationship of an $h R A D 54$ gene polymorphism $(2290 \mathrm{C} / \mathrm{T})$ in an Ecuadorian population with chronic myelogenous leukemia. Genet. Mol. Biol. 2010, 33, 646-649. [CrossRef] [PubMed]

154. Paz-y-Miño, C.; Fiallo, B.F.; Morillo, S.A.; Acosta, A.; Giménez, P.; Ocampo, L.; Leone, P.E. Analysis of the polymorphism [gIVS12-6T > C] in the hMSH2 gene in lymphoma and leukemia. Leuk. Lymphoma 2003, 44, 505-508. [CrossRef] [PubMed]

155. Zaruma-Torres, F.; Lares-Asseff, I.; Reyes-Espinoza, A.; Loera-Castañeda, V.; Chairez-Hernández, I.; Sosa-Macías, M.; Galaviz-Hernández, C.; Almanza-Reyes, H. Association of ABCB1, ABCC5 and xanthine oxidase genetic polymorphisms with methotrexate adverse reactions in Mexican pediatric patients with ALL. Drug Metab. Pers. Ther. 2015, 30, 195-201. [CrossRef] [PubMed]

156. Zaruma-Torres, F.; Lares-Asseff, I.; Lima, A.; Reyes-Espinoza, A.; Loera-Castañeda, V.; Sosa-Macías, M.; Galaviz-Hernández, C.; Arias-Peláez, M.C.; Reyes-López, M.A.; Quiñones, L.A. Genetic polymorphisms associated to folate transport as predictors of increased risk for acute lymphoblastic leukemia in Mexican children. Front. Pharmacol. 2016, 5, 238. [CrossRef] [PubMed]

157. Hishida, A.; Matsuo, K.; Hamajima, N.; Ito, O.; Ogura, M.; Kagami, Y.; Taji, H.; Morishima, Y.; Emi, N.; Tajima, K. Polymorphism in the $h M S H 2$ gene (gIVS $12-67 \rightarrow C$ ) and risk of non-Hodgkin lymphoma in a Japanese population. Cancer Genet. Cytogenet. 2003, 147, 71-74. [CrossRef]

158. Lowsky, R.; DeCoteau, J.; Reitmair, A.; Ichinohasama, R.; Dong, W.; Xu, Y.; Mak, T.; Kadin, M.; Minden, M. Defects of the mismatch repair gene $\mathrm{MSH} 2$ are implicated in the development of murine and human lymphoblastic lymphomas and are associated with the aberrant expression of rhombotin-2 (Lmo-2) and Tal-1 (SLC). Blood 1997, 89, 2276-2282. [PubMed]

159. Ma, L.; Ruan, L.; Liu, H.; Yang, H.; Feng, Y. ABCB1 C3435T polymorphism is associated with leukemia susceptibility: Evidence from a meta-analysis. Onco Targets Ther. 2015, 8, 1009-1015. [PubMed]

160. Zhang, H.; Zhang, Z.; Li, G. ABCB1 polymorphism and susceptibility to acute lymphoblastic leukemia: A meta analysis. Int. J. Clin. Exp. Med. 2015, 8, 7585-7591. [PubMed]

161. Leone, P.E.; Vega, M.E.; Jervis, P.; Pestaña, A.; Alonso, J.; Paz-y-Miño, C. Two new mutations and three novel polymorphisms in the RB1 gene in Ecuadorian patients. J. Hum. Genet. 2003, 48, 639-641. [CrossRef] [PubMed]

162. Mohd Khalid, M.; Yakob, Y.; Yasin, R.; Teik, K.; Siew, C.G.; Rahmat, J.; Ramasamy, S.; Alagaratnam, J. Spectrum of germ-line RB1 gene mutations in Malaysian patients with retinoblastoma. Mol. Vis. 2015, 21, 1185-1190. [PubMed]

163. Badano, I.; Stietz, S.M.; Schurr, T.G.; Picconi, A.M.; Fekete, D.; Quintero, I.M.; Cabrera, M.D.; Campos, R.H.; Liotta, J.D. Analysis of TNF $\alpha$ promoter SNPs and the risk of cervical cancer in urban populations of Posadas (Misiones, Argentina). J. Clin. Virol. 2012, 53, 54-59. [CrossRef] [PubMed]

164. Brenna, S.M.F.; da Silva, I.D.C.G.; Zeferino, L.C.; Pereira, J.; Martinez, E.Z.; Syrjänen, K.J. Prevalence of codon 72 P53 polymorphism in Brazilian women with cervix cancer. Genet. Mol. Biol. 2004, 27, 496-499. [CrossRef]

165. Pan, F.; Tian, J.; Ji, C.; He, Y.; Han, X.; Wang, Y.; Du, J.; Jiang, F.; Zhang, Y.; Pan, Y.; Hu, B. Association of TNF- $\alpha-308$ and -238 polymorphisms with risk of cervical cancer: A meta-analysis. Asian Pac. J. Cancer Prev. 2012, 13, 5777-5783. [CrossRef] [PubMed]

166. Liu, L.; Yang, X.; Chen, X.; Kan, T.; Shen, Y.; Chen, Z.; Hu, Z. Association between TNF- $\alpha$ polymorphisms and cervical cancer risk: A meta-analysis. Mol. Biol. Rep. 2012, 39, 2683-2688. [CrossRef] [PubMed]

167. Li, B.; Wang, X.; Chen, H.; Shang, L.; Wu, N. TP53 codon 72 polymorphism and susceptibility to cervical cancer in the Chinese population: An update meta-analysis. Int. J. Clin. Exp. Med. 2015, 8, 9055-9062. [PubMed]

168. Zhour, R.; Wei, C.; Liu, J.; Luo, Y.; Tang, W. The prognostic value of p53 expression for patients with cervical cancer: A meta analysis. Eur. J. Obstet. Gynecol. Reprod. Biol. 2015, 195, 210-213.

169. Hyman, D.; Taylor, B.; Baselga, J. Implementing genome-driven oncology. Cell 2017, 168, 584-599. [CrossRef] [PubMed] 
170. Rubio-Perez, C.; Tamborero, D.; Schroeder, M.; Antolín, A.; Deu-Pons, J.; Perez-Llamas, C.; Mestres, J.; Gonzalez-Perez, A.; Lopez-Bigas, N. In silico prescription of anticancer drugs to cohort of 28 tumor types reveals targeting opportunities. Cancer Cell 2015, 27, 382-396. [CrossRef] [PubMed]

171. The Cancer Genome Atlas Research Network; Weinstein, J.; Collisson, E.; Mills, G.; Mills, K.; Ozenberger, B.; Ellrott, K.; Shmulevich, I.; Sander, C.; Stuart, J. The Cancer Genome Atlas Pan-Cancer analysis project. Nat. Genet. 2013, 45, 1113-1120.

172. The International HapMap Consortium. A haplotype map of the human genome. Nature 2005, 437, $1299-1320$.

173. The ENCODE Project Consortium. An integrated encyclopedia of DNA elements in the human genome. Nature 2012, 489, 57-74.

(C) 2017 by the authors. Licensee MDPI, Basel, Switzerland. This article is an open access article distributed under the terms and conditions of the Creative Commons Attribution (CC BY) license (http:/ / creativecommons.org/licenses/by/4.0/). 